\title{
Türk ve Dünya Edebiyatından Eserlerin Doğal Dil İşlemeyle İncelenmesi
}

\author{
Dr. Öğr. Üyesi Mehmet Fatih Karaca \\ Tokat Gaziosmanpaşa Üniversitesi, \\ Erbaa Meslek Yüksekokulu \\ Bilgisayar Teknolojileri Bölümü \\ mfkaraca@gmail.com
}

\author{
Dr. Öğr. Üyesi Şafak Bayır \\ Karabük Üniversitesi, \\ Edebiyat Fakültesi \\ Ĕ̆itim Bilimleri Bölümü \\ safakbayir@karabuk.edu.tr
}

Öz

Yayınevleri tarafından ilkokul, ortaokul ve lise seviyesindeki öğrenciler için okuma kitapları hazırlanmaktadır. Bu çalışmada ortaokul öğrencilerine yönelik olan eserler kullanılmıştır. 5 yayınevinden aynı isimli 5 Türk ve 5 dünya edebiyatından eser, doğal dil işleme teknikleriyle Türkçe dil bilgisi kuralları çerçevesinde analiz edilmiştir. Bu çalışmayla eserlerin yazımında ve eserlerdeki Türkçe kullanımında yayınevleri arasındaki farklılık ve benzerlikleri tespit etmek, aynı zamanda Türkçenin kullanım özelliklerini ortaya koymak amaçlanmıştır. İşlemlerin gerçekleştirilmesinde geliştirilen yazılım ve Türkçe doğal dil işleme kütüphanesi Zemberek kullanılmıştır. Eserlerin analiziyle elde edilen sonuçlar 5 yayınevinde oransal olarak benzeşmektedir ve yayınevleri arasındaki farklılıklar genel anlamda düşük seviyededir. Yalnızca çözümlenemeyen kelime sayısı, eserlerin ortalama cümle sayısı, eserlerdeki ortalama kelime sayısı, cümledeki ortalama kelime sayısı ve noktalama işaretlerinin (nokta ve virgül) kullanım oranında yayınevleri arasında ayrışma görülmektedir. Tüm eserler birlikte değerlendirildiğinde cümledeki ortalama kelime sayısı 6.45, kelimedeki ortalama harf sayıs 5.97 ve kelimenin ortalama hece sayısı 2.55'tir. Eserlerde en fazla kullanilan harfler $A, E$ ve $\dot{I}$; en az kullanilanlar $J, F$ ve $P^{\prime}$ dir. Kelimeler en çok $B, K$ ve $D$; en az $J, I$ ve $L$ harfleriyle başlamakta ve en çok $N, E$ ve $A$; en az $C, B$ ve $J$ harfleriyle bitmektedir. En çok kullanılan hece tipi sessiz-sesli, en az kullanılan hece tipi sesli-sessiz-sessizdir. Kelimelerin çoğunluğu ünlü ve ünsüz uyumuna uymaktadır. Ayrıca kelimelerin yaklaşık yarısı isim türünde ve ek almadan kullanılmıştır. Çekim eklerinin toplam kullanım sayısı yapım eklerinin toplam kullanım sayısından fazladır. 17 noktalama işaretinden 12 tanesi eserlerde yer almaktadır. Bununla birlikte farklı yayınevleri tarafından hazırlanıp yayımlanan aynı isimli eser içeriklerinin kısmen veya bütünüyle farklılaşabildiği görülmektedir.

Anahtar Kelimeler: Türk edebiyatı, dünya edebiyatı, doğal dil işleme, Türkçe, dil bilgisi. 


\title{
Analysis of Literary Works from Turkish and World Literature with Natural Language Processing
}

\begin{abstract}
There are various reading books published by many publishers for the students' utilization. Publishers prepare these literary works separately for the stages of primary, secondary and high schools by considering the characteristics of the groups. Literary works prepared for the secondary school students were used in this study. 5 literary works from Turkish and 5 from world literature having the same title out of 5 publishers were analysed by means of NLP (Natural Language Processing) techniques within the setting of Turkish grammar rules. With this study, it is aimed to determine the differences and similarities among publishers in terms of composing literary works and Turkish use in them, at the same time, it is also aimed to reveal the distinctive characteristics of the Turkish use. Developed software and Zemberek, Turkish NLP Library, were used in the analysis processes. Results which were obtained via analyses of literary works were found out as similar in terms of proportion and the differences were at the low level in general among 5 publishers. Differences were only found out in terms of unanalysable word number, average sentence number of literary works, average word number in literary works, average word number in a sentence and the ratio of the use of punctuation marks (dot and comma). Despite the fact that the titles of the literary works are the same among publishers, these distinctions occurred as a result of the difference in terms of the contents.
\end{abstract}

Keywords: Turkish literature, world literature, natural language processing, Turkish, grammar. 


\section{GİRIŞ}

Çeşitli seviyelere yönelik farklı isimlerde okuma kitapları olsa da bunların en yaygını ve en çok bilineni 100 Temel Eser listesidir. 100 Temel Eser, öğrencilerin boş zamanlarını değerlendirmek ve öğrencilere okuma alışkanlığını kazandırmak amacıyla tavsiye edilmiş edebi eserlerdir. Millî Eğitim Bakanlığı, 04.08.2005 tarihinde ilköğretim okullarında okutulacak 100 Temel Eser konulu bir genelge yayımlamış (Millî Eğitim Bakanlığı [MEB], 2005) ve Türkçe dersi müfredatıyla ilişkili olan kaynak eserler genelge ile belirlenmiştir. Sonrasında birtakım sebepler nedeniyle bazı eserler çıkartılmış veya yenileri listeye eklenmiştir. 2018 yılında ise 100 Temel Eser uygulamasının kaldırılmasına karar verilmiştir (MEB, 2018).

Farklı yayınevleri tarafından hazırlanmış Türk ve dünya edebiyatından seçilerek oluşturulan eser (100 Temel Eser) setlerinin ilkokul, ortaokul ve lise öğrencilerine yönelik olanları mevcuttur. Yayınevleri tarafından hazırlanan bu setler farklı eserlerden meydana gelebilmektedir; bir yayınevi setinde var olan bir eser başka bir yayınevi setinde yer almayabilir.

Türk ve dünya edebiyatından oluşan eserler doğal dillerde yazılmış metinlerdir. Fakat eser içeriklerinin yapay zekâ ve dil bilimin alt birimi olan doğal dil işleme (DDI) teknikleriyle incelendiği bir çalışma bulunmamaktadır.

Doğal dil ne zaman ortaya çıtığı bilinmeyen, süreç içerisinde kuralları oluşan ve bu kuralların sınırında gelişen iletişim aracıdır. DDİ ise yazılı metin, fotoğraf, video, ses veya başka biçimlerde bulunabilen, doğal dillerle oluşturulmuş ifadelerin (metinlerin) dijital ortama aktarılarak bilgisayar aracılığıyla dilin kendi kuralları çerçevesinde çözümlenmesi, anlaşılması ve yeniden üretilmesidir. DDİ çalışmalarında çalışmanın yapıldığı dilin özellikleri iyi bilinmeli, dile hâkim olunmalı ve dil kuralları olan bir bütün sistem olarak değerlendirilmelidir. Dili oluşturan bu kuralların tümüne dil bilgisi denir.

Şimdiki zaman ve I. tekil şahsa göre Türkçede geliyorum şeklinde (gel-iyor-um) çekimlenerek kullanılan gelmek fiili, İngilizcede I am coming (come -ing) şeklinde kullanılmaktadır. Görüldüğü üzere; Türkçede şahıs eki şimdiki zamanda fiilde görülmekteyken (geliyorum, geliyorsun) İngilizcede görülmemektedir (I am coming, You are coming). Bu ve bunun gibi diğer bütün dil bilgisi olayları dilin kuralları çerçevesinde gerçekleşmektedir. Her dil farklı dil bilgisi özelliği gösterdiğinden ve dillerin kendine has özellikleri olduğundan çalışmanın yapılacağı dil için DDİ adımları oluşturulmalı ve bu adımlar ilgili metinde işletilmelidir. Ayrıca, bir dil için oluşturulmuş DDİ adımları, başka dillerdeki metinlerde aynı sonucu vermeyebilir.

DDİ, insan bilgisayar etkileşiminin seviyesini belirlemesi açısından yüksek bir öneme sahiptir; DDI'de ne kadar başarılı olunursa, insan-bilgisayar etkileşimi seviyesinin yükseltimesinde de o denli başarılı olunacaktır. Yazım hatası düzeltimi (Çakiroğlu \& Özyurt, 2006), soru-cevap sistemleri (Amasyalı \& Diri, 2005), metin sinıflandırma (Özdoğan \& Turan, 2019) ve daha farklı konulardaki çalışmalarda (Uzundere, Dedja, Diri \& Amasyalı, 2018; Kuşçu, 2015) DDİ'nin kullanıldı ğı görülmektedir. Bunlarla sınırlı ve bunlardan ibaret olmayan DDİ'ye, esasında doğal dillerin yer aldığı bütün uygulamalarda, doğal dillerde yazılmış metinlerle işlem yapmak için başvurulabilmektedir.

DDİ çalışmalarında metni oluşturan kelimelerin kök/gövdelerinin bulunması önemli bir yer tutar. Bunun için morfemlerin (morphem - biçimbirim) tespit edilmesi gerekir. Bir 
dilin morfemlerinin araştırılması biçim bilim, şekil bilim veya morfoloji olarak isimlendirilir (Karaağaç \& Yavuzer, 2011, s. 49). Dil bilgisinin en geniş ve en önemli dallarından biri olan morfoloji ile kök, gövde, kelimeler, kelimelerin türü ve onların aldığı ekler incelenir (Hengirmen, 2007, s. 111). Morfolojik analiz yanı sıra DDİ'nin ses bilgisi, söz dizimi veya anlam bilim gibi alt alanları vardır. Fonetik veya ses bilimi şeklinde isimlendirilen ses bilgisi ile bir dildeki ses özellik ve olayları, söz dizimi alanında bir cümleyi oluşturan sözcüklerin dizilimi, anlam bilim alanında ise sözcüklerin karşıladıkları anlamlar ve sözcük öbeklerinin anlamsal ilişkisi incelenir.

Tablo 1. Eserlerin İncelendiği Çalışmalar

\begin{tabular}{|c|c|c|}
\hline Konu & Lisansüstü Tez & Makale \\
\hline $\begin{array}{l}\text { Eserlerde vurgulanan değerler ve } \\
\text { temalar }\end{array}$ & $\begin{array}{l}\text { Şen, 2007; Kılıç, 2010; Sivrikaya, } \\
\text { 2010; Aktan, 2012; Gedik, 2012; } \\
\text { Kızılkaya, 2012; Kurttekin, 2013; } \\
\text { Öztürk, 2013; Kantar, 2014; } \\
\text { Çalışkan, 2016; Erdemir, 2016 }\end{array}$ & $\begin{array}{l}\text { Karaman Kepenekçi \& } \\
\text { Aslan, 2013; Türkyılmaz } \\
\text { \& Kuş, 2014; Kılıç \& } \\
\text { Aktan, 2015; Eker \& } \\
\text { Yıldırım, } 2017 \\
\end{array}$ \\
\hline $\begin{array}{l}\text { Öğrencilerin eserleri okuma alışkanlığı, } \\
\text { tutumları ve oranları ile sebepleri }\end{array}$ & $\begin{array}{l}\text { Arıcan, 2010; Karakaş, 2013; } \\
\text { Parlak, } 2014\end{array}$ & Arı \& Okur, 2014 \\
\hline Eserlerin hedef kitleye uygunluğu & $\begin{array}{l}\text { Doğan, 2011; Ulutaş, 2011; } \\
\text { Yurtseven, 2011; Alemdar Özer, } \\
2012\end{array}$ & $\begin{array}{l}\text { Arıcan \& Yılmaz, 2010; } \\
\text { Çifçi \& Ulutaş, } 2017\end{array}$ \\
\hline Eserlerin sözcük kazanımına katkısı & $\begin{array}{l}\text { Okur, 2007; Akçay, 2009; Paksu, } \\
2010\end{array}$ & Kara \& Ulutaş, 2018 \\
\hline Eserlerde deyim ve atasözü kullanımı & Tozoğlu, 2009; İspir, 2013 & Bayraktar Erten, 2016 \\
\hline Diğer & $\begin{array}{l}\text { Birkan Baydan, 2008; Süngü, } \\
\text { 2011; Tenekeci, 2011; Erdemir, } \\
\text { 2016; Özdoğan Şahin, 2018; } \\
\text { Güzelküçük, } 2019\end{array}$ & $\begin{array}{l}\text { Ceran, 2015; Çer, 2016; } \\
\text { Çer, } 2017\end{array}$ \\
\hline
\end{tabular}

Alan yazın incelemesi lisansüstü tezler ve konuyla ilgili çalışmalar olmak üzere 2 farklı kategoride yapılmıştır. Eserlerle alakalı yapılan çalışmalar ve ilgili oldukları konulara ilişkin bilgiler Tablo 1'de verilmiştir. Ulusal Tez Merkezi'nde tez başlığında 100 Temel Eser geçen 1 doktora ve 29 yüksek lisans olmak üzere 30 lisansüstü tez tespit edilmiştir (Yükseköğretim Kurulu Başkanlığı, 2019). Hem erişime açık lisansüstü tezlerde hem de akademik çalışmalarda ağırlıklı olarak eserlerde vurgulanan değerlerin, eserlerin okuma alışkanlığına olan etkilerinin ve hedef kitleye uygunluğu konularının ele alındığı görülmüştür.

Eserlerde vurgulanan değerlerin araştırıldığı çalışmada en fazla vurgulanan değerlerin sevgi, yardımseverlik ve saygi; en az vurgulanan değerlerin ise emaneti korumak, feragat ve istişare olduğu tespit edilmiştir (Kılıç \& Aktan, 2015). Farklı bir çalışmada ise eserlerdeki 30 yerli romanın insan hakları konusuna yer verme düzeyleri belirlenmiş, eserlerde en fazla barış ve halk, en az demokrasi ve hoşgörü alt kategorilerine yer verildiği görülmüştür (Karaman Kepenekci \& Aslan, 2013). Eserlerde çocuk haklarına yer verilme düzeylerinin incelendiği çalışmada ise yaşama ve korunma hakkının eserlerde çok yer aldığ belirtilmiştir (Türkyılmaz \& Kuş, 2014). En çok okunan eserlerle öğrencilerin zevk alarak ve merak ederek okudukları eserlerin paralel oldukları (Arı \& Okur, 2014), Türkçe öğretmenlerinin 100 Temel Eser uygulamasının genel anlamda çok başarılı olmadığını belirttikleri ve eserlerin öğrenciler için çok uygun olduğunu düşünmedikleri ifade edilmiştir 
(Arıcan \& Yılmaz, 2010). 100 Temel Eser genelgesinin hedefine ulaşmasının olanaksız olduğu, listedeki eserlerin hangi ölçütlere göre seçildiğinin belirli olmadığı, eserlerin bakanlıkça değil yayınevleri tarafından hazırlandığı ve bunun da eserlerde tahrif ve telif sorunlarına sebebiyet verdiği, uygulama ile genel anlamda okuma alışkanlığı kültürü seviyesinde gelişme görülmediği, hatta uygulamanın çocuk-kitap etkileşimini olumsuz etkilediği ve velilerin uygulamadan habersiz oldukları belirtilmiştir (Çocuk Vakfı, 2009). Okunabilirlik düzeylerinin konu edinildiği çalışmada 100 Temel Eser listesinden 5, 6, 7 ve 8. sınıf öğrencileri için tavsiye edilen Türk edebiyatı kategorisindeki 49 kitaptan 24'ünün kolay, 19'unun orta ve 6'sının zor düzeyde olduğu belirlenmiştir (Ceran, 2015).

Özetle; araştırmacılar tarafından çeşitli özellikleri bakımından incelenmiş olmasına karşın, eserlerin bu çalışma kapsamında değerlendirilen boyutlarıyla ele alındığı benzer bir çalışmaya rastlanmamıştır.

\section{Çalışmanın Amacı}

Yapılan alan yazın incelemesi neticesinde, Türk ve dünya edebiyatından eserlerin Türkçe dil bilgisi kuralları bakımından ele alınmadığı görülmüştür. Bu sebeple bu çalışmada, eserlerin Türkçe DDİ teknikleriyle incelemesi gerçekleştirilmiştir. Bu yolla Türkçenin genel kullanım özelliklerinin ve Türkçeye ilişkin durumların istatistiksel olarak ortaya konulması amaçlanmıştır. Ayrıca bu çalışmayla şu sorulara yanıt aranmıştır;

$\checkmark$ Eserlerin yazımında yayınevlerinde görülen farklılık ve benzerlikler nelerdir?

$\checkmark$ Eserlerde aşağıdaki özelliklere göre kullanım sıklıkları nelerdir?

○ Harf,

- Konumlarına göre harf,

- Bigramlarda ikili harf takipleri,

- Tiplerine göre harf,

- Harf sayılarına göre kelime,

- Hece sayılarına göre kelime,

○ Harf sayılarına göre hece,

- Hece tipleri,

○ Çözümleme sayılarına göre kelime,

- Ek sayılarına göre kelime,

○ Türlerine göre kelime.

$\checkmark$ Eserlerde yapım ve çekim eklerinden hangileri kullanılmaktadır, bunların kullanım sıklıkları nelerdir?

$\checkmark$ Eserlerdeki kelimeler ses uyum kurallarına ne ölçüde uymaktadır?

$\checkmark$ Eserlerde noktalama işaretlerinden hangileri kullanılmaktadır, bunların kullanım sıklıkları nelerdir? 


\section{YÖNTEM}

\section{Veri Kümesi}

Bu çalışmada, ortaokul grubuna yönelik olarak hazırlanmış Y1, Y2, Y3, Y4 ve Y5 olarak etiketlendirilen 5 yayınevinden eserler kullanılmıştır. 5 Türk (Nasreddin Hoca Hikâyeleri, Keloğlan Masalları, Mevlana'nın Mesnevisinden Seçme Hikâyeler, Ömer'in Çocukluğu, Yalnız Efe) ve 5 dünya (Ezop Masalları, La Fontaine'den Seçmeler, Andersen Masalları, Hikâyeler, Değirmenimden Mektuplar) edebiyatından olmak üzere ve her bir yayınevinden seçilen onar eserle çalışma gerçekleştirilmiştir. Çalışmaya yayınevlerinde ortak olarak yer alan eserler dâhil edilmiştir.

Tablo 2. Eser Adları ve Alt Bölüm (Hikâye) Sayıları

\begin{tabular}{lllllll} 
& & \multicolumn{3}{c}{ Yayınevleri } & & \\
\cline { 2 - 6 } & Eser Ad1 & Y1 & Y2 & Y3 & Y4 & Y5 \\
\hline \multirow{5}{*}{ Türk Edebiyatı } & Nasreddin Hoca Hikâyeleri & 152 & 137 & 77 & 44 & 49 \\
& Keloğlan Masalları & 13 & 18 & 8 & 5 & 8 \\
& Mevlana'nın Mesnevisinden Seçme Hikâyeler & 33 & 78 & 8 & 27 & 27 \\
& Ömer'in Çocukluğu & 21 & 1 & 17 & 26 & 1 \\
& Yalnız Efe & 7 & 9 & 3 & 3 & 4 \\
\hline \multirow{5}{*}{ Dünya Edebiyatı } & Ezop Masalları & 140 & 40 & 52 & 36 & 37 \\
& La Fontaine'den Seçmeler & 93 & 40 & 40 & 26 & 30 \\
& Hikâyeler & 7 & 7 & 2 & 14 & 7 \\
& Değirmenimden Mektuplar & 19 & 24 & 19 & 7 & 3 \\
& & 15 & 27 & 8 & 18 & 20 \\
\hline
\end{tabular}

Veri kümesini oluşturan eserlerin isimleri ve alt hikâye sayılarına ilişkin bilgiler Tablo 2 'de sunulmuştur. Eserlerde yayınevleri arasında alt bölüm sayısı bakımından farklılıklar bulunmaktadır. Bütün yayınevleri toplu olarak değerlendirildiğinde en fazla alt bölümlü (toplam 459) eser Nasreddin Hoca Hikâyeleri iken en az alt bölümlü (toplam 26) eser Yalnız Efe'dir.

Aynı isimli eser içeriklerinin yayınevlerinde farklı olabildiği görülmüştür. Örneğin; Nasreddin Hoca Hikâyeleri'nde Y1 yayınevinde 152 hikâye varken Y4 yayınevinde 44 hikâye yer almaktadır. Nasreddin Hoca Hikâyeleri adlı eserin hikayalerden oluştuğu ve bu sebeple farklılaşma olduğu düşünülebilir. Fakat diğer eserlerde de buna benzer içerik farklılaşması tespit edilmiştir.

\section{Verilerin İşlenmesi}

Çalışma kapsamında işlemler, Zemberek ve geliştirilen yazılım olmak üzere iki aşamalı yürütülmüştür. Kelimelerin denetlenmesinde, kök/gövde tespitinde, hecelenmesinde, eklerine ayrılmasında ve türlerinin belirlenmesinde Zemberek kullanılmıştır. Bunlar dışındaki bütün işlemler, Visual Studio ortamında ve C\# dilinde geliştirilen yazılımla gerçekleştirilmiştir. 
Tablo 3. DDI Adımlarının Gerçekleştirilme Şekilleri

\begin{tabular}{|c|c|c|}
\hline İşlem & Geliştirilen Yazılımla & Zemberek'le \\
\hline Eserlerin ön işlemden geçirilmesi & $\bullet$ & \\
\hline Eserlerin kelimelere parçalanması & $\bullet$ & \\
\hline Kelimelerin denetlenmesi & & $\bullet$ \\
\hline Kelimelerin kök/gövdelerinin tespiti & & $\bullet$ \\
\hline Cümle ve kelime (kök/gövde) sayılarının tespiti & • & \\
\hline En çok kullanılan kök/gövde ve kullanım sayılarının tespiti & $\bullet$ & \\
\hline Harflerin kullanım sayılarının tespiti & $\bullet$ & \\
\hline Harflerin konumlarına göre kullanım sayılarının tespiti & $\bullet$ & \\
\hline Bigramlarda harflerin birbirlerini takip sayılarının tespiti & $\bullet$ & \\
\hline Tiplerine göre harflerin kullanım sayılarının tespiti & $\bullet$ & \\
\hline Uzunluklarına göre kelime sayılarının tespiti & $\bullet$ & \\
\hline Kelimelerin hecelenmesi & & $\bullet$ \\
\hline Hecelerine göre kelime sayılarının tespiti & • & \\
\hline Harflerine göre hece sayılarının tespiti & $\bullet$ & \\
\hline Hece tipleri ve kullanım sayılarının tespiti & $\bullet$ & \\
\hline En çok kullanılan heceler ve kullanım sayılarının tespiti & • & \\
\hline Çözümleme sonuçlarına göre kelime sayılarının tespiti & $\bullet$ & \\
\hline Kelimelerin eklerine ayrılması & & $\bullet$ \\
\hline Ek sayısına göre kelime sayılarının tespiti & $\bullet$ & \\
\hline Yapım eklerinin kullanım sayılarının tespiti & $\bullet$ & \\
\hline Çekim eklerinin kullanım sayılarının tespiti & • & \\
\hline Kelime türlerinin belirlenmesi & & $\bullet$ \\
\hline Türlerine göre kelime sayılarının tespiti & $\bullet$ & \\
\hline Ses uyumu kontrolü & $\bullet$ & \\
\hline Ses uyumuna göre kelime sayılarının tespiti & $\bullet$ & \\
\hline Noktalama işaretlerinin kullanım sayılarının tespiti & $\bullet$ & \\
\hline
\end{tabular}

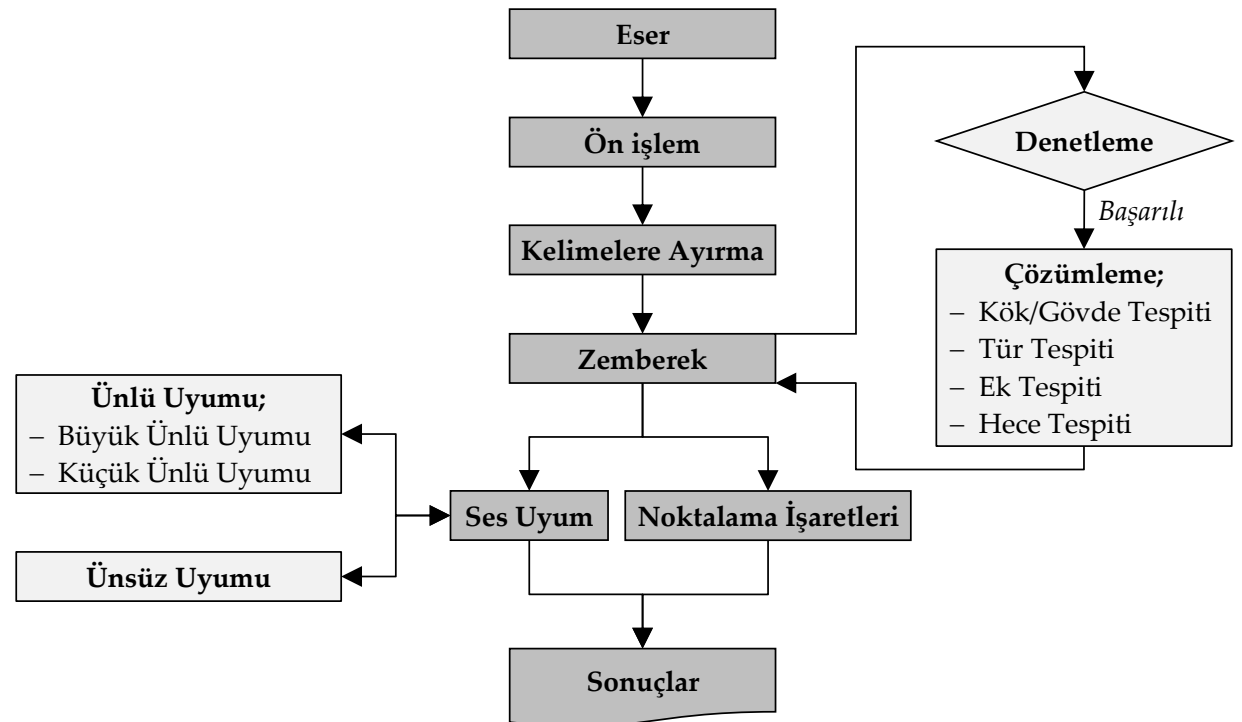

Şekil 1. Geliştirilen Yazılıma Ait Çalışma Şeması 
Tablo 3'te görüleceği üzere işlemlerin büyük kısmında, özellikle sonuçların elde edilmesinde çalışma şeması Şekil 1'de verilen ve bu çalışma için geliştirilen yazılımdan faydalanılmıştır.

Şekil 1'e göre her bir eser öncelikle sisteme verilmekte, ardından eserler ön işlemden geçirilmekte, eser kelimelere parçalanmakta, her bir kelimenin Türkçe denetimi yapılmakta, denetimde başarılı olan kelimelerin çözümlenmesi gerçekleştirilmekte, ses uyum kontrolü ve kullanılan noktalama işaretleri belirlendikten sonra sonuçlar elde edilmektedir. Denetleme, çözümleme öncesi bir işlemdir; ilgili kelimeye çözümleme işleminin uygulanabilir olup olmadığını gösterir. Denetleme sonucu Başarılı ise o kelime çözümleme işlemine girer, değilse girmez ve dikkate alınmaz.

Yalnızca Türkçe için değil diğer Türk dilleri için de temel DDİ sistemi olan Zemberek (Akın \& Akın, 2007), açık kaynak kodlu bir Türkçe doğal dil işleme kütüphanesidir (Zemberek, 2015). Türkçe metinlerle yapılan birçok çalışmada (Aydin \& Hallac, 2015; Gunduz \& Cataltepe, 2015; Akarsu \& Diri, 2016; Arslan, 2016; Yılmaz, 2018; Yüksel \& Tan, 2018) tercih edilmiştir. Birçok özelliği bulunmasına karşın çalışmalarda genellikle Zemberek'in kelimelerin kök/gövde tespit etme özelliğinden faydalanılmaktadır.

Tablo 4. Zemberek Çözümleme Örnekleri

\begin{tabular}{|c|c|c|c|c|c|c|c|}
\hline Kelime & Denetleme & Tür & Kök/Gövde & Heceleme & $\begin{array}{l}\text { Ek } \\
\text { Say1sı }\end{array}$ & Ekler & Ayrıştırma \\
\hline nerdeyse & Başarısız & - & - & - & - & - & - \\
\hline kral & Başarılı & İsim & Kral & - & 1 & ISIM_KOK & kral \\
\hline göz & Başarılı & İsim & Göz & göz & 1 & ISIM_KOK & göz \\
\hline \multirow{3}{*}{ aslan } & \multirow{3}{*}{ Başarılı } & İsim & Aslan & \multirow{3}{*}{ as lan } & 1 & ISIM_KOK & aslan \\
\hline & & İsim & Asla & & 2 & $\begin{array}{l}\text { ISIM_KOK, } \\
\text { ISIM_SAHIPLIK_BEN_IM }\end{array}$ & asla $n$ \\
\hline & & İsim & As & & 3 & $\begin{array}{l}\text { ISIM_KOK, } \\
\text { ISIM_DONUSUM_LE, } \\
\text { FIIL_EDILGENSESLI_N }\end{array}$ & as la $n$ \\
\hline
\end{tabular}

Tablo 4'te 4 kelimenin Zemberek çözümleme örnekleri görülmektedir. nerdeyse kelimesinin denetleme sonucu Başarısızdır; yani kelimenin morfolojik analizleri gerçekleştirilmemiştir. nerdeyse kelimesi yerine neredeyse kullanılsaydı denetleme sonucu Başarılı olacak ve kelime çözümleme işlemine girecekti. kral kelimesi incelendiğinde kelimenin denetlemede Başarılı olduğu ve heceleme dışındaki diğer çözümlemelerde sonuçlar ürettiği görülmüştür. Türkçede heceler iki sessiz harfle başlamadığından kral kelimesi hecelenememiştir. göz kelimesi incelendiğinde ise bu kelimenin heceleme dahil olmak üzere tüm morfolojik analizleri gerçekleştirilmiştir. kral ve göz kelimeleri ile tek sonuç elde edilmişken aslan kelimesinde 1 ekli, 2 ekli ve 3 ekli olmak üzere 3 çözümleme sonucu Zemberek tarafından sunulmuştur. Bu tip çoklu çözümlemeli durumlarda en uzun kök/gövdeye sahip olan ilk çözümleme, aranılan çözümleme olarak kabul edilerek işlemler gerçekleştirilmiştir. 


\section{BULGULAR}

Türkçe dil bilgisi kuralları kapsamında DDİ adımlarının eserlere uygulanmasıyla elde edilen sonuçlar, Tablo 5 ile Tablo 22 arasında verilmiştir. Bu sonuçlar, eserlerin yazımında ve bu eserlerdeki Türkçe kullanımında yayınevleri arasında farklılık ve benzerlikleri tespit etmek, aynı zamanda bu yolla Türkçenin genel karakterini ortaya koymak bakımından ele alınmıştır.

Tablo 5. Cümle ve Kelime (kök/gövde) Sayıları

\begin{tabular}{llllll}
\cline { 2 - 6 } & Y1 & Y2 & Y3 & Y4 & Y5 \\
\hline Cümle Sayısı & 21906 & 25202 & 10866 & 18175 & 14278 \\
Çözümlenemeyen Kelime Sayısı & 2640 & 3856 & 1388 & 1784 & 2411 \\
Ayrık (benzersiz) Kelime (kök/gövde) Sayısı & 5648 & 6032 & 4013 & 4442 & 5124 \\
Toplam Kelime (kök/gövde) Sayısı & 141858 & 172248 & 68710 & 98812 & 101494
\end{tabular}

Çözümlenemeyen (denetimde başarılı olamayanlar) kelimeler, kapsam dışında tutulmuş, sadece Tablo 5'te bilgi amaçlı verilmiştir. Kelime ve cümle sayıları incelendiğinde şu sonuçlar elde edilmiştir;

$\checkmark$ Çözümlenemeyen kelimeler sayısal olarak en fazla Y2' de yer almıştır.

$\checkmark$ Bütün eserler, 7759 ayrık kelimenin toplamda 583122 kez kullanılmasıyla oluşturulmuştur.

$\checkmark 60.00$ olan bir eserdeki ortalama cümle sayısı yayınevlerinde sırasıyla 43.81, 66.15, $46.44,88.23$ ve $76.76^{\prime}$ dir.

$\checkmark 386.94$ olan bir eserdeki ortalama kelime sayısı yayınevlerinde sırasıyla 283.72, 452.09, $293.63,479.67$ ve $545.67^{\prime}$ dir.

$\checkmark 6.45$ olan bir eserdeki cümlenin ortalama kelime sayısı yayınevlerinde sırasıly 6.48, $6.32,6.83,5.44$ ve $7.11^{\prime}$ dir.

Tablo 6. En Çok Kullanılan 10 Kök/Gövde ve Kullanım Sayıları

\begin{tabular}{lllll}
\hline Y1 & Y2 & Y3 & Y4 & Y5 \\
\hline bir 5352, & bir 6185, de(mek) & bir 2493, de(mek) & bir 3364, de(mek) & bir 3721, de(mek) \\
de(mek) 3110, & 3803, bu 3280, & 1542, ol(mak) & 2228, ol(mak) 1467, & 2145, ol(mak) 1700, \\
ol(mak) 2412, bu & ol(mak) 3040, ben & 1190, bu 1073, ben & bu 1422, ben 1063, & bu 1566, ve 1297, \\
2335, ben 1583, & 1842, ne 1494, ve & 781, ve 744, ne & gel(mek) 786, ne 756, & ben 1112, ne 877, o \\
ne 1430, ve 1202, & 1337, o 1323, & 596, gel(mek) 488, & için 637, çok 595, & 720, et(mek) 700, \\
$\begin{array}{l}\text { o 985, gel(mek) } \\
\text { 952, gel(mek) 1264, } 878\end{array}$ & et(mek) 1235 & o 462, sen 446 & git(mek) 579 & gel(mek) 692 \\
\hline
\end{tabular}

Eserlerde en çok kullanılan 10 kelime kök/gövde ve kullanım sayıları Tablo 6'da verilmiştir;

$\checkmark$ Yayınevlerinde en fazla kullanılan 2 kök/gövde bir ve de(mek)dir.

$\checkmark$ 3. kök/gövdeden sonra yayınevleri arasında en çok kullanılan kök/gövdede farklılaşma başlamıştır.

$\checkmark$ Y1'de 1368, Y2'de 1440, Y3'te 1088, Y4'te 1167 ve Y5'te 1443 kök/gövde 1 kez kullanılmıştır.

$\checkmark$ Tüm yayınevleri birlikte değerlendirildiğinde en fazla kullanılan 5 kök/gövde ve kullanım sayıları şöyledir; bir 21115, de(mek) 12828, ol(mak) 9809, bu 9676, ben 6381. 
Tablo 7. Harflerin Kullanım Sayıları

\begin{tabular}{llllll}
\cline { 2 - 5 } Y1 & Y2 & Y3 & Y4 & Y5 \\
\hline A & 99182 & 121240 & 47140 & 70859 & 70533 \\
B & 25324 & 30805 & 12041 & 16743 & 17810 \\
C & 8044 & 9700 & 4043 & 5799 & 6024 \\
Ç & 10333 & 12563 & 5197 & 8148 & 8095 \\
D & 38059 & 49082 & 19816 & 26752 & 29393 \\
E & 73596 & 91379 & 36106 & 51005 & 53661 \\
F & 2947 & 4428 & 1378 & 2114 & 2376 \\
G & 11667 & 14057 & 5465 & 8289 & 8155 \\
G & 9724 & 11579 & 4661 & 7201 & 7158 \\
H & 9654 & 11998 & 4769 & 6047 & 7031 \\
I & 44038 & 52181 & 21514 & 32577 & 31510 \\
I & 66303 & 82934 & 31960 & 45933 & 48075 \\
J & 71 & 54 & 15 & 44 & 28 \\
K & 40101 & 48625 & 19665 & 29576 & 29440 \\
L & 47009 & 56730 & 22404 & 33695 & 33762 \\
\hline
\end{tabular}

\begin{tabular}{llllll}
\cline { 2 - 5 } & Y1 & Y2 & Y3 & Y4 & Y5 \\
\hline M & 33900 & 38201 & 15922 & 25053 & 22521 \\
$\mathbf{N}$ & 61634 & 75058 & 29828 & 43664 & 43568 \\
$\mathbf{O}$ & 20891 & 24755 & 11000 & 14918 & 14873 \\
$\ddot{O}$ & 7853 & 9098 & 3852 & 5749 & 5501 \\
$\mathbf{P}$ & 7791 & 8905 & 3225 & 5197 & 5196 \\
$\mathbf{R}$ & 59358 & 72021 & 28397 & 41347 & 42049 \\
$\mathbf{S}$ & 23787 & 29169 & 11720 & 16661 & 16649 \\
$\mathbf{S}$ & 20877 & 22780 & 10062 & 16430 & 12903 \\
$\mathbf{T}$ & 22855 & 29690 & 10984 & 15970 & 17857 \\
$\mathbf{U}$ & 28719 & 34866 & 14286 & 20288 & 20348 \\
$\ddot{\mathbf{U}}$ & 17576 & 21489 & 8954 & 12836 & 13141 \\
$\mathbf{V}$ & 7848 & 9749 & 4045 & 5252 & 6163 \\
$\mathbf{Y}$ & 29178 & 35317 & 14622 & 20624 & 20324 \\
$\mathbf{Z}$ & 12880 & 15962 & 6336 & 9090 & 9210 \\
\hline
\end{tabular}

Harflerin kullanım sayıları Tablo 7' de verilmiştir;

$\checkmark$ Tüm yayınevlerinde en fazla kullanılan harfler $A, E, \dot{I}, N, R, L$ ve $I$ iken en az kullanılan harfler $J, F, P, \ddot{O}$ ve $V^{\prime}$ dir.

$\checkmark$ Tüm harflerin yaklaşı $\% 42.65$ 'i sesli, \%57.35'i sessiz harftir.

$\checkmark$ Alfabede olmayan $\mathrm{Q}, \mathrm{X}$ ve $\mathrm{W}$ harflerinin eserlerde özel isimlerde kullanıldığ görülmüştür. 
Tablo 8. Harflerin Konumlarına Göre Kullanım Sayıları

\begin{tabular}{|c|c|c|c|c|c|c|c|c|c|c|c|c|c|c|c|c|c|c|c|c|c|c|c|c|}
\hline & 1 & 2 & 3 & 4 & 5 & 6 & 7 & 8 & 9 & 10 & 11 & 12 & 13 & 14 & 15 & 16 & 17 & 18 & 19 & 20 & 21 & 22 & 23 & 24 \\
\hline A & 42205 & 119720 & 23539 & 80581 & 44196 & 29296 & 32010 & 13621 & 10853 & 6727 & 3185 & 1734 & 734 & 344 & 135 & 44 & 18 & 7 & 4 & 1 & - & - & - & - \\
\hline B & 83108 & 470 & 9575 & 5560 & 2566 & 528 & 732 & 132 & 17 & 28 & 2 & 3 & - & 2 & - & - & - & - & - & - & - & - & - & - \\
\hline C & 3500 & 1551 & 10344 & 3881 & 4975 & 4822 & 1812 & 1258 & 768 & 378 & 200 & 68 & 32 & 16 & 3 & - & - & 1 & 1 & - & - & - & - & - \\
\hline D & 54072 & 6982 & 18963 & 24202 & 12659 & 18678 & 7626 & 7855 & 5287 & 2665 & 2176 & 947 & 583 & 255 & 77 & 47 & 14 & 5 & 4 & 1 & 3 & 1 & E & - \\
\hline$E$ & 19036 & 107680 & 12411 & 54156 & 35842 & 21582 & 25359 & 10887 & 9028 & 5198 & 1969 & 1478 & 625 & 287 & 138 & 32 & 22 & 7 & 4 & 3 & 1 & 1 & 1 & - \\
\hline F & 4774 & 1653 & 3342 & 524 & 2532 & 305 & 88 & 23 & 1 & 1 & - & - & - & - & - & - & - & - & - & - & - & - & - & - \\
\hline G & 41522 & 8 & 1215 & 4232 & 118 & 240 & 269 & 15 & 13 & 1 & - & - & - & - & - & - & - & - & - & - & - & - & - & - \\
\hline Ğ & - & 6426 & 10232 & 1930 & 8374 & 4922 & 2765 & 2796 & 1488 & 740 & 343 & 156 & 85 & 40 & 10 & 15 & - & - & - & 1 & - & - & - & - \\
\hline H & 25629 & 1710 & 7704 & 780 & 1991 & 671 & 903 & 106 & 1 & - & - & - & 4 & - & - & - & - & - & - & - & - & - & - & - \\
\hline I & 1140 & 19994 & 6932 & 35863 & 24863 & 26812 & 25685 & 13777 & 11804 & 6626 & 3824 & 2336 & 1083 & 643 & 275 & 85 & 58 & 12 & 5 & 1 & 1 & 1 & - & - \\
\hline I & 24880 & 71927 & 15658 & 52390 & 30520 & 20677 & 23116 & 11812 & 11336 & 5328 & 3780 & 1961 & 907 & 491 & 204 & 103 & 71 & 12 & 19 & 6 & 3 & 2 & 1 & 1 \\
\hline $\mathbf{J}$ & 61 & 63 & 40 & 23 & 6 & - & 10 & 9 & - & - & - & - & - & - & - & - & - & - & - & - & - & - & - & - \\
\hline $\mathbf{K}$ & 62801 & 6227 & 34070 & 15274 & 18467 & 11302 & 6414 & 5756 & 3323 & 2046 & 851 & 520 & 242 & 58 & 35 & 17 & 2 & - & - & - & 1 & - & 1 & - \\
\hline $\mathbf{L}$ & 1234 & 23739 & 52313 & 34548 & 26100 & 28578 & 10825 & 7655 & 4865 & 1864 & 1055 & 467 & 203 & 99 & 30 & 17 & 6 & 2 & - & - & - & - & - & - \\
\hline $\mathbf{M}$ & 11771 & 4194 & 27080 & 26465 & 19234 & 19285 & 9974 & 6737 & 4849 & 2704 & 1685 & 897 & 441 & 178 & 65 & 28 & 6 & 3 & - & 1 & - & - & - & - \\
\hline Ö & 8586 & 23174 & 6 & 59 & 196 & 8 & 3 & 20 & - & - & 1 & - & - & - & - & - & - & - & - & - & - & - & - & - \\
\hline $\mathbf{P}$ & 8351 & 821 & 12122 & 1821 & 4036 & 756 & 1354 & 673 & 155 & 169 & 47 & 6 & 1 & 2 & - & - & - & - & - & - & - & - & - & - \\
\hline $\mathbf{R}$ & 2716 & 11750 & 93706 & 19554 & 35649 & 20181 & 17098 & 18341 & 10334 & 6834 & 3950 & 1761 & 714 & 345 & 134 & 58 & 23 & 15 & 6 & 3 & - & - & - & - \\
\hline$S$ & 39835 & 8248 & 15600 & 8773 & 10105 & 8295 & 2182 & 3059 & 821 & 574 & 295 & 107 & 50 & 25 & 6 & 2 & 4 & 3 & 2 & - & - & - & - & - \\
\hline Ş & 8324 & 6046 & 20395 & 3850 & 13626 & 11624 & 3750 & 7695 & 2839 & 2071 & 1306 & 713 & 420 & 174 & 149 & 45 & 12 & 10 & 2 & - & - & 1 & - & - \\
\hline $\mathbf{T}$ & 17116 & 8000 & 25493 & 16742 & 9008 & 9987 & 6191 & 1614 & 1937 & 694 & 282 & 172 & 60 & 28 & 16 & 12 & 3 & 1 & - & - & - & - & - & - \\
\hline $\mathbf{U}$ & 6432 & 35488 & 9829 & 24630 & 14860 & 7652 & 5771 & 4437 & 4089 & 2026 & 1891 & 823 & 278 & 212 & 49 & 21 & 10 & 8 & 1 & - & - & - & - & - \\
\hline Ü & 4523 & 28304 & 3287 & 19511 & 8254 & 4262 & 3781 & 954 & 730 & 228 & 113 & 29 & 11 & 8 & 1 & - & - & - & - & - & - & - & - & - \\
\hline $\mathrm{V}$ & 13535 & 4516 & 11555 & 1872 & 815 & 471 & 154 & 59 & 43 & 27 & 5 & 5 & - & - & - & - & - & - & - & - & - & - & - & - \\
\hline $\mathbf{Y}$ & 36108 & 8401 & 30843 & 4873 & 14854 & 9962 & 6190 & 5427 & 1558 & 1047 & 492 & 175 & 86 & 33 & 8 & 6 & 1 & 1 & - & - & - & - & - & - \\
\hline Z & 4919 & 5393 & 22510 & 1525 & 4847 & 4370 & 2645 & 2569 & 1441 & 1347 & 624 & 642 & 286 & 200 & 95 & 34 & 17 & 6 & 4 & 3 & 1 & - & - & - \\
\hline
\end{tabular}


Mehmet Fatih Karaca-Şafak Bayır

Tablo 9. Bigramlarda Harflerin Birbirlerini Takip Sayılar

\begin{tabular}{|c|c|c|c|c|c|c|c|c|c|c|c|c|c|c|c|c|c|c|c|c|c|c|c|c|c|c|c|c|c|c|}
\hline & \# & $\mathbf{A}^{2}$ & $\mathrm{~B}^{2}$ & $C^{2}$ & $C^{2}$ & $D^{2}$ & $\mathrm{E}^{2}$ & $\mathbf{F}^{2}$ & $\mathrm{G}^{2}$ & $\breve{G}^{2}$ & $\mathbf{H}^{2}$ & $\mathbf{I}^{2}$ & $\dot{\mathbf{I}}^{2}$ & $\mathrm{~J}^{2}$ & $\mathbf{K}^{2}$ & $\mathrm{~L}^{2}$ & $\mathbf{M}^{2}$ & $\mathrm{~N}^{2}$ & $\mathrm{O}^{2}$ & $\ddot{\mathrm{O}}^{2}$ & $\mathbf{P}^{2}$ & $\mathbf{R}^{2}$ & $S^{2}$ & $S^{2}$ & $\mathbf{T}^{2}$ & $\mathbf{U}^{2}$ & $\ddot{\mathbf{U}}^{2}$ & $\mathbf{V}^{2}$ & $\mathbf{Y}^{2}$ & $\mathrm{Z}^{2}$ \\
\hline $\mathbf{A}^{1}$ & 68493 & 570 & 7023 & 5824 & 3966 & 18255 & & 2977 & 171 & 11402 & 9380 & & 642 & 20 & 27011 & 27035 & 22002 & 53048 & 1 & & 7778 & 66518 & 12449 & 14738 & 12836 & 9 & & 6150 & 21012 & 8765 \\
\hline $\mathbf{B}^{1}$ & 12 & 23054 & 130 & - & - & 51 & 12748 & - & F & F & - & 1603 & 39796 & - & - & 193 & - & 1 & 2828 & 1926 & - & 364 & - & - & - & 15682 & 4276 & - & 3 & 36 \\
\hline \begin{tabular}{l|}
$C^{1}$ \\
\end{tabular} & 1 & 12458 & 24 & 113 & - & 42 & 11239 & - & - & - & - & 3639 & 2394 & - & - & 34 & . & 25 & 55 & 15 & - & 66 & & & & 2584 & 916 & & & 4 \\
\hline$D^{1}$ & 73 & 38904 & 16 & - & - & 395 & 42753 & - & - & - & 16 & 17651 & 31965 & - & - & 40 & 1 & & 4625 & 2404 & - & 76 & & - & & 16247 & 7835 & - & 74 & . \\
\hline $\mathrm{E}^{1}$ & 69489 & 12 & 1244 & 5306 & 3124 & 12314 & 1 & 2009 & 19 & 6926 & 1109 & & 38 & 65 & 19027 & 20448 & 15232 & 43415 & 3 & - & 2052 & 51721 & 10244 & 5265 & 11383 & - & 4 & 7737 & 13805 & 3628 \\
\hline $\mathbf{F}^{1}$ & 872 & 4210 & 1 & 4 & 39 & 10 & 2490 & 50 & 2 & - & 1 & 1406 & 1493 & - & 291 & 416 & 6 & 7 & 120 & - & - & 462 & 38 & & 1161 & 120 & 30 & & 5 & 1 \\
\hline $\mathrm{G}^{\mathbf{1}}$ & & 1814 & F & - & - & - & 14223 & - & - & - & - & 1057 & 10587 & - & - & F & - & & 117 & 9904 & . & 64 & & & & 701 & 8822 & - & . & - \\
\hline $\mathbf{H}^{1}$ & 2192 & 13918 & 110 & 7 & 590 & 23 & 7412 & 2 & - & - & 6 & 1656 & 4429 & - & 198 & 601 & 282 & 68 & 4003 & 10 & 15 & 332 & 241 & 82 & 1177 & 681 & 279 & 165 & 98 & 82 \\
\hline $\mathbf{I}^{1}$ & 44214 & 1 & 67 & 925 & 602 & 1076 & - & 175 & - & 4877 & 22 & - & - & - & 12298 & 9492 & 9660 & 41411 & F & - & 3426 & 16692 & 3576 & 16030 & 621 & - & - & 533 & 7843 & 8107 \\
\hline$\dot{\mathbf{I}}^{1}$ & 58736 & 143 & 4232 & 962 & 9175 & 3651 & - & 1492 & 92 & 4933 & 1218 & - & 104 & 1 & 8572 & 17344 & 14894 & 48523 & 2 & - & 2790 & 40113 & 7905 & 18081 & 5023 & - & - & 660 & 16687 & 9683 \\
\hline $\mathbf{J}^{1}$ & 12 & 55 & - & 3 & - & 89 & 3 & - & - & - & - & F- & 23 & - & - & 3 & 1 & & & - & - & $T$ & & & & 21 & 2 & 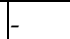 & & - \\
\hline $\mathbf{K}^{1}$ & 34386 & 33101 & 91 & 7 & 1020 & 58 & 15282 & 5 & 6 & - & 3 & 11701 & 15115 & - & 1134 & 12186 & 3821 & 57 & 8096 & 3745 & & 1394 & 2283 & 874 & 8611 & 9290 & 4040 & 8 & 168 & 3 \\
\hline $\mathbf{L}^{1}$ & 8952 & 57189 & 1049 & 381 & 363 & 10697 & 42341 & 41 & 1203 & & 39 & 15265 & 15912 & - & 2975 & 5350 & 10391 & 665 & 2367 & 2 & 78 & & 1484 & & 2520 & 7911 & 4757 & 259 & 164 & 14 \\
\hline $\mathbf{M}^{1}$ & 26431 & 28157 & 812 & 454 & 49 & 2742 & 20047 & 1 & 5 & - & 6 & 17415 & 18793 & - & 295 & 2434 & 226 & 140 & 255 & 137 & 315 & 389 & 1431 & 503 & 46 & 10234 & 4032 & 3 & 66 & 93 \\
\hline $\mathbf{N}^{1}$ & 89609 & 18522 & 344 & 7209 & 1234 & 28092 & 21195 & 19 & 1500 & & 21 & 20225 & 20610 & 19 & 1459 & 12982 & 5212 & 1080 & 269 & 84 & 14 & 3194 & 2728 & 37 & 1221 & 10766 & 4219 & 3 & 655 & 451 \\
\hline$\ddot{O ̈}^{1}$ & 133 & - & 281 & 158 & 73 & 199 & - & 262 & - & 1163 & 25 & . & - & - & 1186 & 2288 & 559 & 4285 & - & - & 1174 & 6503 & 923 & 444 & 1710 & - & - & 521 & 6568 & 3596 \\
\hline $\mathbf{P}^{1}$ & 8371 & 7506 & - & 1 & 34 & 3 & 3817 & - & - & - & 112 & 2563 & 663 & - & 286 & 1826 & 776 & 1 & 442 & 2 & 4 & 1126 & 845 & 44 & 1262 & 277 & 330 & & 16 & - \\
\hline $\mathbf{R}^{1}$ & 67097 & 28073 & 1322 & 940 & 1211 & 21425 & 16344 & 62 & 1029 & & 371 & 20141 & 22125 & 2 & 7804 & 10849 & 14907 & 755 & 659 & - & 677 & 112 & 5082 & 1612 & 5849 & 8527 & 5298 & 235 & 245 & 174 \\
\hline $\mathbf{S}^{1}$ & 1956 & 15553 & 62 & 15 & 12 & 16 & 13804 & 1 & - & F & 27 & 15753 & 15202 & - & 1454 & 2868 & 637 & 122 & 8266 & 3735 & 67 & 419 & 633 & - & 7445 & 6426 & 3224 & 29 & 211 & - \\
\hline Ş & 29044 & 7707 & 45 & 7 & 256 & - & 6278 & 6 & 33 & - & 48 & 7922 & 4588 & - & 1762 & 9165 & 3208 & 52 & 18 & 415 & 9 & 17 & 371 & 1 & 6691 & 2968 & 2212 & 98 & 79 & - \\
\hline $\mathrm{T}^{1}$ & 7979 & 16891 & 14 & - & 528 & - & 12490 & 169 & 16 & - & 72 & 13918 & 12489 & - & 315 & 4821 & 5451 & 23 & 2359 & 119 & 6 & 1050 & 638 & - & 4612 & 6349 & 6866 & 8 & 93 & 2 \\
\hline $\mathbf{U}^{1}$ & 28397 & 259 & 396 & 837 & 864 & 1346 & 2 & 194 & 223 & 4500 & 597 & & 1 & 11 & 4044 & 7946 & 6950 & 19077 & & - & 1111 & 14150 & 2566 & 8675 & 3129 & E & - & 1131 & 7406 & 4627 \\
\hline$\ddot{\mathbf{U}}_{1}$ & 7861 & 1 & 342 & 984 & 2525 & 521 & 8 & 267 & - & 1100 & 77 & - & - & 26 & 5271 & 4798 & 3456 & 16318 & - & - & 841 & 7149 & 2101 & 5767 & 2004 & - & - & 431 & 4562 & 7578 \\
\hline $\mathrm{V}^{1}$ & 706 & 9573 & 24 & 410 & - & 632 & 11940 & - & 466 & & 63 & 294 & 2782 & - & 102 & 1484 & 252 & & 44 & & - & 1473 & 103 & 409 & 1 & 1694 & 331 & 225 & 1 & 6 \\
\hline $\mathbf{Y}^{1}$ & 2976 & 31891 & 493 & 69 & - & 3430 & 18050 & 143 & 519 & & 94 & 7685 & 7859 & & 647 & 10340 & 1624 & 1397 & 18573 & 536 & 1 & 1384 & 725 & & 186 & 4591 & 5730 & 844 & 50 & 79 \\
\hline$Z^{1}$ & 0 & 7127 & Th & 24 & - & 2078 & 579 & _ & 793 & & 4 & 52 & 3654 & $1-$ & 116 & 5094 & 1082 & & 48 & & & 159 & 101 & & & 1656 & 81 & & 90 & 60 \\
\hline
\end{tabular}

ali kelimesinde 2 bigram vardır; al ve $l i$. al için $\mathrm{A}^{1}$ satırı ile $\mathrm{L}^{2}$ sütununun, $l$ i için ise $\mathrm{L}^{1}$ satırı ile $\mathrm{I}^{2}$ sütununun kesissim noktasının değerleri 1 arttırılır.

\#: kelimenin bitiş harfini ifade eder. Örneğin $\mathrm{A}^{1}$ satırı ve \# sütununun kesiştiği hücrede A harfiyle biten kelime sayısı belirtilmektedir (68493).

1: bigramda ilk harfi ifade eder.

2:bigramda ikinci harfi ifade eder 
Harflerin konumlarına göre kullanım sayılarını ve bigramlarda birbirlerini takip sayılarını belirlemek amacıyla tüm yayınevlerindeki eserler birleştirilmiştir. Harflerin kelime içindeki konumuna (kelime içerisinde kaçıncı harf olduğuna) ilişkin sonuçlar Tablo 8'de verilmiştir;

$\checkmark \breve{G}$ harfi dışındaki bütün harflerle başlayan en az 1 kelime vardır.

$\checkmark$ Kelimeler en çok sırasıyla $B, K, D, A$ ve $G$ harfleriyle başlamıştır.

$\checkmark$ Kelimeler en az sırasiyla J, $I, L, R$ ve $C$ harfleriyle başlamıştır.

$\checkmark \dot{I}$ ve $N, 24$ harfli olan kelimelerin (en uzun kelimeler) son harfleridir.

$\checkmark \dot{I}$ her konumda yer alan tek harftir.

$\checkmark \quad I$ dışındaki tüm sesli harfler en çok ikinci harf olarak kelimelerde yer almıştır.

Eserlerin birleştirilmiş hallerinden bigramlar (2 harfliler) meydana getirilerek harflerin takip sayıları elde edilmiş ve sonuçlar Tablo 9' da sunulmuştur;

$\checkmark$ G harfi dışındaki bütün harflerle biten en az 1 kelime vardır.

$\checkmark$ Kelimeler en çok sırasıyla $N, E, A, R$ ve $\dot{I}$ harfleriyle bitmiştir.

$\checkmark$ Kelimeler en az sırasıyla $C, J, B, D$ ve $O ̈$ harfleriyle bitmiştir.

$\checkmark 2887227$ bigram belirlenmiştir.

$\checkmark A R, L A$ ve $E R$ en çok kullanılan bigramlardır.

$\checkmark$ Bigramlar en çok sırasıyla $A, E, \dot{I}, N$ ve $R$ harfleriyle bitmiştir.

$\checkmark$ Bigramlar en az sırasıyla $J, G, F, H$ ve $V$ harfleriyle bitmiştir.

Tablo 10. Tiplerine Göre Harflerin Kullanım Sayıları

\begin{tabular}{|c|c|c|c|c|c|c|c|c|}
\hline & & & & & & & & \\
\hline & & & & Y1 & Y2 & Y3 & Y4 & Y5 \\
\hline \multirow{8}{*}{ Sesli Harf } & \multirow{4}{*}{ Düz } & \multirow{2}{*}{ Geniş } & Kalın & 99182 & 121240 & 47140 & 70859 & 70533 \\
\hline & & & İnce & 73596 & 91379 & 36106 & 51005 & 53661 \\
\hline & & \multirow{2}{*}{ Dar } & Kalın & 44038 & 52181 & 21514 & 32577 & 31510 \\
\hline & & & İnce & 66303 & 82934 & 31960 & 45933 & 48075 \\
\hline & \multirow{4}{*}{ Yuvarlak } & \multirow{2}{*}{ Geniş } & Kalın & 20891 & 24755 & 11000 & 14918 & 14873 \\
\hline & & & İnce & 7853 & 9098 & 3852 & 5749 & 5501 \\
\hline & & \multirow{2}{*}{ Dar } & Kalın & 28719 & 34866 & 14286 & 20288 & 20348 \\
\hline & & & İnce & 17576 & 21489 & 8954 & 12836 & 13141 \\
\hline \multirow{4}{*}{ Sessiz Harf } & \multirow{2}{*}{ Sert } & \multirow{2}{*}{\multicolumn{2}{|c|}{$\begin{array}{l}\text { Süreksiz } \\
\text { Sürekli }\end{array}$}} & 81080 & 99783 & 39071 & 58891 & 60588 \\
\hline & & & & 57265 & 68375 & 27929 & 41252 & 38959 \\
\hline & \multirow{2}{*}{ Yumuşak } & \multicolumn{2}{|c|}{ Süreksiz } & 83094 & 103644 & 41365 & 57583 & 61382 \\
\hline & & \multicolumn{2}{|c|}{ Sürekli } & 261602 & 314671 & 126230 & 185970 & 184783 \\
\hline
\end{tabular}

Tiplerine göre harflerin kullanım sayıları Tablo 10'da verilmiştir;

$\checkmark$ Eserlerde kalın sesli harflerin ince sesli harflerden, geniş sesli harflerin dar sesli harflerden ve düz sesli harflerin yuvarlak sesli harflerden fazla olduğu görülmüştür.

$\checkmark$ Sert süreksiz sessiz harflerin sert sürekli sessiz harflerden, yumuşak sürekli sessiz harflerin yumuşak süreksiz sessiz harflerden ve yumuşak sessiz harflerin sert sessiz harflerden fazla olduğu belirlenmiştir. 
$\checkmark$ Düz dar ince sesli olanlar hariç olmak üzere tüm sesli harflerde kalın sesli olanların ince seslilerden fazla olduğu tespit edilmiştir.

Tablo 11. Uzunluğuna Göre Kelime Sayıları

\begin{tabular}{|c|c|c|c|c|c|}
\hline & Y1 & Y2 & Y3 & Y4 & Y5 \\
\hline 1 Harfli & 914 & 1198 & 425 & 467 & 675 \\
\hline 2 Harfli & 10376 & 12916 & 4704 & 5997 & 7267 \\
\hline 3 Harfli & 16533 & 19402 & 8124 & 11053 & 11502 \\
\hline 4 Harfli & 16400 & 19847 & 8136 & 10924 & 12018 \\
\hline 5 Harfli & 25577 & 31285 & 12148 & 18012 & 18723 \\
\hline 6 Harfli & 18239 & 21482 & 8736 & 13369 & 12475 \\
\hline 7 Harfli & 16517 & 20575 & 8173 & 11904 & 12069 \\
\hline 8 Harfli & 13425 & 15815 & 6456 & 9792 & 9645 \\
\hline 9 Harfli & 9334 & 11644 & 4584 & 6850 & 6515 \\
\hline 10 Harfli & 6393 & 7992 & 3162 & 4537 & 4750 \\
\hline 11 Harfli & 3898 & 4667 & 1946 & 2821 & 2706 \\
\hline 12 Harfli & 2106 & 2802 & 1090 & 1649 & 1583 \\
\hline 13 Harfli & 1145 & 1382 & 555 & 801 & 780 \\
\hline 14 Harfli & 577 & 695 & 268 & 398 & 424 \\
\hline 15 Harfli & 257 & 315 & 111 & 142 & 216 \\
\hline 16 Harfli & 101 & 134 & 61 & 54 & 76 \\
\hline 17 Harfli & 43 & 54 & 16 & 24 & 43 \\
\hline 18 Harfli & 14 & 24 & 10 & 9 & 12 \\
\hline 19 Harfli & 6 & 9 & 2 & 8 & 6 \\
\hline 20 Harfli & 2 & 4 & 1 & - & 3 \\
\hline 21 Harfli & 1 & 5 & - & - & 3 \\
\hline 22 Harfli & - & 1 & 1 & 1 & 1 \\
\hline 23 Harfli & - & - & - & - & 1 \\
\hline 24 Harfli & - & - & 1 & - & 1 \\
\hline
\end{tabular}

Uzunluklarına göre kelime sayıları Tablo 11'de verilmiştir;

$\checkmark$ Tüm kelimeler dikkate alındığında kelimelerin ortalama harf sayısı 5.97' dir.

$\checkmark$ Tüm kelimelerin \%30.68'inin 4 ve daha az sayıda, \%51.19'unun ise 6 ve daha fazla sayıda harften meydana geldiği ve ağırlı̆̆ı \%18.13 ile 5 harfte olduğu görülmüştür.

Kelimeler en az 1, en fazla 24 harften meydana gelmiştir; «o», «şiirselleştirilmesindeki, tutuklayabileceklerinden». 
Tablo 12. Hecelerine Göre Kelime Sayıları

\begin{tabular}{llllll} 
& Y1 & Y2 & Y3 & Y4 & Y5 \\
\hline Hecelenemeyen & 227 & 348 & 149 & 171 & 156 \\
$\mathbf{1}$ Heceli & 25603 & 30877 & 11869 & 15941 & 17846 \\
$\mathbf{2}$ Heceli & 50481 & 60559 & 24540 & 35048 & 36343 \\
$\mathbf{3}$ Heceli & 39027 & 46943 & 18905 & 28574 & 27832 \\
$\mathbf{4}$ Heceli & 19352 & 24223 & 9708 & 13897 & 14081 \\
$\mathbf{5}$ Heceli & 5767 & 7484 & 2877 & 4292 & 4160 \\
$\mathbf{6}$ Heceli & 1170 & 1523 & 549 & 772 & 901 \\
$\mathbf{7}$ Heceli & 198 & 236 & 89 & 97 & 143 \\
$\mathbf{8}$ Heceli & 32 & 51 & 18 & 17 & 23 \\
$\mathbf{9}$ Heceli & 1 & 4 & 4 & 3 & 7 \\
$\mathbf{1 0}$ Heceli & - & - & 2 & - & 2 \\
\hline
\end{tabular}

Hecelerine göre kelime sayıları Tablo 12'de verilmiştir;

$\checkmark$ Tüm kelimelerin ortalama hece sayısı 2.55'tir.

$\checkmark$ Kelimeler en fazla 10 hecelidir; «ger-çek-leş-ti-re-me-ye-ce-ği-ni, tu-tuk-la-ya-bi-le-cek-le-rini, şi-ir-sel-leş-ti-ril-me-sin-de-ki».

Kök/gövde tespiti yapıldığı halde hecelenemeyen kelimelerin Türkçenin hece yapısına uymayacak şekilde 2 ünsüzle başladıkları görülmüştür; «kral, plan, prens».

Tablo 13. Harflerine Göre Hece Sayıları

\begin{tabular}{llllll} 
& Y1 & Y2 & Y3 & Y4 & Y5 \\
\hline 1 Harfli & 17848 & 21349 & 8792 & 12936 & 12964 \\
2 Harfli & 201068 & 251094 & 99270 & 140875 & 145903 \\
3 Harfli & 138027 & 163979 & 66158 & 99279 & 97832 \\
4 Harfli & 1617 & 1948 & 778 & 1191 & 1127 \\
\hline
\end{tabular}

Harflerine göre hece sayıları Tablo 13'te verilmiştir;

$\checkmark$ Tüm hecelerin ortalama harf sayısı 2.34'tür.

$\checkmark$ Heceler en az 1, en fazla 4 harflidir; «a-vi, i-ki-si, o-lan», «dost-lu-ğu-mu-za, girt-la-ğ1na, çift-çi».

$\checkmark$ Tüm hecelerin $\% 4.98^{\prime}$ i 1, \%56.48'i 2, \%38.09'u 3 ve \%0.45'i ise 4 harflidir.

Tablo 14. Hece Tiplerinin Kullanım Sayıları (V:Sesli Harf, C: Sessiz Harf)

\begin{tabular}{llllll} 
& Y1 & Y2 & Y3 & Y4 & Y5 \\
\hline sesli (V) & 17848 & 21349 & 8792 & 12936 & 12964 \\
sesli-sessiz (VC) & 14877 & 18475 & 7419 & 10385 & 10674 \\
sessiz-sesli (CV) & 186191 & 232619 & 91851 & 130490 & 135229 \\
sessiz-sesli-sessiz (CVC) & 137837 & 163768 & 66057 & 99127 & 97640 \\
sesli-sessiz-sessiz (VCC) & 190 & 211 & 101 & 152 & 192 \\
sessiz-sesli-sessiz-sessiz (CVCC) & 1617 & 1948 & 778 & 1191 & 1127 \\
\hline
\end{tabular}


Hece tiplerinin kullanım sayıları Tablo 14'te verilmiştir;

Tüm hecelerin yaklaşık \%4.98'i bir sesli harften, \%4.17'si sesli-sessiz harf birleşiminden, \%52.32'si sessiz-sesli harf birleşiminden, \%38.03'ü sessiz-sesli-sessiz harf birleşiminden, $\% 0.06$ 's s sesli-sessiz-sessiz harf birleşiminden ve $\% 0.45^{\prime}$ i sessiz-sesli-sessizsessiz harf birleşiminden meydana gelmiştir.

Tablo 15. En Çok Kullanılan 10 Hece ve Kullanım Sayıları

\begin{tabular}{lllll}
\hline Y1 & Y2 & Y3 & Y4 & Y5 \\
\hline la 8214, de 7034, & la 10195, de 8909, & la 4012, de 3543, le & la 6125, de 4924, & la 5810, de 5096, le \\
le 6727, bir 5989, & le 8563, di 7747, & 3267, di 3002, da & le 4769, da 4006, & 5007, di 4697, bir \\
di 5639, da 5522, a & da 7313, bir 6876, & 2826, bir 2808, a & ya 3903, a 3877, & 4136, da 4035, a \\
5394, ya 5302, ka & ya 6362, ka 6154, a & 2597, ya 2571, ne & bir 3835, di 3608, & 3612, ya 3522, ka \\
4758, ne 4665 & 6105, ne 5734 & 2276, ra 2128 & ka 3319, ra 3159 & 3467, ne 3097 \\
\hline
\end{tabular}

Eserlerde en fazla kullanılan 10 hece ve kullanım sayıları Tablo 15 'te verilmiştir;

$\checkmark l a$, de ve le yayınevlerinde en fazla kullanilan 3 hecedir.

$\checkmark$ 3. heceden sonra yayınevlerinde kullanılan hecelerde farklılaşma görülmeye başlanmıştır.

$\checkmark 1$ kez kullanılmış hece sayısı yayınevlerinde sırasıyla 209, 200, 195, 213 ve 207' dir.

Tablo 16. Çözümleme Sonuçlarına Göre Kelime Sayıları

\begin{tabular}{|c|c|c|c|c|c|}
\hline & \\
\hline & $\mathrm{Y1}$ & Y2 & Y3 & Y4 & Y5 \\
\hline 1 Cözümlemeli & 71175 & 88828 & 34537 & 48431 & 52553 \\
\hline 2 Cözümlemeli & 33642 & 39651 & 16304 & 23258 & 23377 \\
\hline 3 Cözümlemeli & 19632 & 23232 & 9494 & 14309 & 13545 \\
\hline 4 Cözümlemeli & 11636 & 13538 & 5529 & 8435 & 8032 \\
\hline 5 Cözümlemeli & 2170 & 2628 & 1088 & 1620 & 1547 \\
\hline 6 Cözümlemeli & 2434 & 3077 & 1164 & 1902 & 1655 \\
\hline 7 Cözümlemeli & 304 & 319 & 147 & 220 & 196 \\
\hline 8 Cözümlemeli & 450 & 510 & 231 & 348 & 330 \\
\hline 9 Cözümlemeli & 202 & 207 & 103 & 121 & 117 \\
\hline 10 Cözümlemeli & 58 & 58 & 27 & 42 & 32 \\
\hline 11 Cözümlemeli & 43 & 48 & 21 & 40 & 36 \\
\hline 12 Cözümlemeli & 78 & 114 & 44 & 64 & 47 \\
\hline 13 Cözümlemeli & 8 & 1 & 3 & 3 & - \\
\hline 14 Cözümlemeli & 1 & 8 & 1 & 9 & 7 \\
\hline 15 Cözümlemeli & 12 & 3 & 9 & 2 & 3 \\
\hline 16 Cözümlemeli & 304 & 14 & 147 & 4 & 11 \\
\hline 17 Cözümlemeli & - & - & - & 1 & - \\
\hline 18 Cözümlemeli & 8 & 7 & 3 & - & 2 \\
\hline 20 Cözümlemeli & 2 & 1 & 2 & 2 & - \\
\hline 23 Cözümlemeli & 1 & 1 & 1 & - & - \\
\hline 24 Cözümlemeli & - & - & - & 1 & 1 \\
\hline 25 Cözümlemeli & 1 & 1 & 1 & - & - \\
\hline 28 Cözümlemeli & - & - & - & - & 2 \\
\hline 32 Cözümlemeli & - & - & 1 & - & - \\
\hline 33 Cözümlemeli & 1 & 1 & - & - & - \\
\hline 40 Cözümlemeli & - & - & - & - & 1 \\
\hline 48 Çözümlemeli & - & 1 & - & - & - \\
\hline
\end{tabular}


Çözümleme neticesinde kelimelerin olası kök/gövdeleri ve aldıkları ekler Zemberek'le belirlenmiştir. Kelimenin 1 çözümlemeli olması kök/gövde şeklinde bulunduğunu ve herhangi bir ek almadığını, 2 ve daha fazla çözümlemeli olması ise çekim veya yapım eki aldığını gösterir. Çözümleme sonuçlarına göre kelime sayıları Tablo $16^{\prime}$ da verilmiştir;

$\checkmark$ Kelimelerin \%97.93'ü Zemberek tarafından başarılı şekilde çözümlendiği belirlenmiştir.

$\checkmark$ Çözümlenemeyenler incelendiğinde, bu kelimelerin çoğunlukla tek harfli, seslenme ifadesi, özel isim (veya yabancı kelime), söyleyiş farklığı (şive) veya yanlış yazım gibi özelliklerde oldukları tespit edilmiştir; «heey, Cornille, ordan».

$\checkmark$ En fazla çözümlemeye sahip «anlaşmazlıklarına» kelimesi için Zemberek tarafından 48 çözümleme sunulmuştur. Bu çözümleme sonuçlarına göre ilgili kelime için 3 kök/gövde tespit edilmiştir; «anlaş» ve «anla» için 12 'şer, «an» için 24 çözümleme gerçekleştirilmiştir.

$\checkmark$ Kelimelerin \% 50.68'i 1, \%23.36'sı 2 çözümlemelidir.

$\checkmark$ Kelimeler yapısal olarak incelendiğinde 1 ve 2 çözümlemeli kelimelerin çoğunlukta olduğu bilgisine ulaşılmıştır.

Tablo 17. Eklerine Göre Kelime Sayıları

\begin{tabular}{llllll} 
& Y1 & Y2 & Y3 & Y4 & Y5 \\
\hline 0 Ekli & 63226 & 76915 & 30039 & 41610 & 45004 \\
$\mathbf{1}$ Ekli & 43889 & 52510 & 21509 & 32264 & 31400 \\
$\mathbf{2}$ Ekli & 26638 & 32570 & 13111 & 19113 & 19114 \\
$\mathbf{3}$ Ekli & 6841 & 8715 & 3395 & 5019 & 5077 \\
$\mathbf{4}$ Ekli & 1085 & 1357 & 559 & 720 & 773 \\
$\mathbf{5}$ Ekli & 167 & 167 & 89 & 79 & 116 \\
$\mathbf{6}$ Ekli & 2 & 17 & 8 & 7 & 8 \\
7 Ekli & - & - & - & - & 1 \\
8 Ekli & - & - & - & - & 1 \\
\hline
\end{tabular}

Zemberek'te 116 adet ek adı vardır. Bu ekler, çözümleme örneklerine bakılarak sınıflandırılmış ve sonuç itibariyle 7 birleşik fiil, 53 yapım ve 45 çekim ekinin eserlerde kullanıldığı görülmüştür. Birleşik fiil eklerinin yayınevlerindeki kullanım sayısı sırayla 2070, $2497,936,1275$ ve 1380 'dir.

Aldığı ek sayılarına göre kelime sayıları Tablo 17'de verilmiştir;

$\checkmark 0$ ekli, herhangi bir ek almamış kelimeyi ifade etmektedir.

$\checkmark$ Tüm kelimelerin \%44.04'ü hiçbir ek almadan kullanılmıştır. Bu da kelimelerin Türkçede daha çok ek almamış kök/gövde şeklinde kullanıldığını göstermektedir.

$\checkmark$ Kelimelerin en fazla 8 ekli olduğu görülmüştür; «şiirselleştirilmesindeki» $\rightarrow$ «şiir-sel-leştir-il-me-si-nde-ki», Eklerin Zemberek karşılığı: «ISIM_KOK, ISIM_ILISKILI_SEL, ISIM_DONUSUM_LES, FIIL_ETTIRGEN_TIR, FIIL_EDILGEN_IL, FIIL_DONUSUM_ME, ISIM_SAHIPLIK_O_IIISIM_KALMA_DE, ISIM_BULUNMA_KI».

Tablo 18. Yapım Eklerinin Kullanım Sayıları

\begin{tabular}{llllll} 
& Y1 & Y2 & Y3 & Y4 & Y5 \\
\hline Fiil $\rightarrow$ Sifat Fiil & 4417 & 5935 & 2074 & 3058 & 3301 \\
Fiil $\rightarrow$ Zarf Fiil & 3691 & 4115 & 1678 & 2466 & 2316 \\
Fiil $\rightarrow$ Fiil & 7280 & 8795 & 3603 & 5106 & 5282 \\
Fiil $\rightarrow$ İsim & 3042 & 3681 & 1521 & 2213 & 2247 \\
$\dot{\text { Isim }} \rightarrow$ İ & 4680 & 5557 & 2343 & 3396 & 3600 \\
$\dot{\text { Isim }} \rightarrow$ Fiil & 278 & 359 & 145 & 254 & 235 \\
\hline
\end{tabular}

SEFAD, 2020; (44): 379-404 
Yapım ekleri, 6 sınıfta gruplandırılmıştır; fiilden sıfat fiil («kop asıca»), zarf fiil («aş ıp»), fiil («sesle $n$ miş») ve isim («kurtul uş») türetenler ile isimden isim («üç gen») ve fiil («adım la») türetenlerdir. Yapım eklerinin türlerine göre kullanım sayıları Tablo 18'de verilmiştir verilmiştir;

$\checkmark$ Tüm eserlerde toplam 96668 yapım eki kullanılmıştır.

Eklerin \%21.57'si isimden, \%78.43'ü fiilden türetme yapmıştır.

Eklerin \%33.39'u isim, \%66.61'i fiil türetmek için kullanılmıştır.

Tablo 19. Çekim Eklerinin Kullanım Sayıları

\begin{tabular}{llllll}
\cline { 2 - 6 } & Y1 & Y2 & Y3 & Y4 & Y5 \\
\hline Çokluk Eki & 8125 & 10043 & 3938 & 6010 & 6171 \\
Ekeylem & 1930 & 2271 & 924 & 1215 & 1329 \\
Hal Eki & 26001 & 32158 & 12656 & 18619 & 18443 \\
İyelik Eki & 28336 & 35312 & 13571 & 20297 & 20123 \\
Şahıs Eki & 5648 & 6411 & 2484 & 3919 & 4023 \\
Tasarlama Kipi & 3102 & 3605 & 1427 & 1984 & 1911 \\
Zaman Kipi & 24335 & 29406 & 13345 & 19052 & 18233 \\
\hline
\end{tabular}

Çekim ekleri çokluk eki («insan lar»), ekeylem («şans lı yım»), hal eki («ev de»), iyelik eki («ben im»), şahıs eki («eğlen ir iz»), tasarlama kipi («katıl sa») ve zaman kipi («de miş») olmak üzere 7 sınıfta gruplandırılmıştır. Çekim eklerinin türlerine göre kullanım sayıları Tablo 19'da verilmiştir;

$\checkmark$ Tüm eserlerde toplam 406357 çekim eki kullanılmıştır.

$\checkmark$ İyelik ve hal eki ile zaman kipi, en fazla kullanılan ilk üç çekim eki türüdür.

$\checkmark$ İsim türündeki kelimelerin aldıkları çekim eki sayısı, fiil türündeki kelimelerin aldıkları çekim eki sayısının yaklaşık 2 katıdır.

Geçmiş zaman eki en fazla, gelecek zaman eki en az sayıda kullanılan zaman kipidir.

Tablo 20. Türlerine Göre Kelime Sayıları

\begin{tabular}{llllll} 
& Y1 & Y2 & Y3 & Y4 & Y5 \\
\hline Bağlaç & 447 & 818 & 184 & 261 & 350 \\
Edat & 1228 & 1667 & 571 & 911 & 881 \\
Fiil & 41006 & 49217 & 19972 & 29077 & 29026 \\
İmek (Ek Fiil) & 75 & 199 & 38 & 49 & 77 \\
İsim & 72426 & 87329 & 34656 & 50869 & 52296 \\
Kisaltma & 4 & 11 & 3 & 13 & 4 \\
Özel & 867 & 1250 & 503 & 533 & 670 \\
Say1 & 6856 & 8136 & 3283 & 4269 & 4780 \\
Sifat & 6914 & 8500 & 3693 & 4952 & 5226 \\
Soru & 897 & 909 & 324 & 451 & 457 \\
Ünlem & 34 & 25 & 9 & 12 & 14 \\
Yank1 & 263 & 258 & 139 & 140 & 170 \\
Zaman & 3390 & 4437 & 1761 & 2620 & 2500 \\
Zamir & 7451 & 9492 & 3574 & 4655 & 5043 \\
\hline
\end{tabular}


Türlerine göre kelime sayıları Tablo 20'de verilmiştir;

Kelimelerin \%28.86'sı fiil, \%51.03'ü isim türündedir.

$\checkmark$ Kisaltma ve ünlem, eserlerde en az sayıda kullanılan türlerdir.

Tablo 21. Ünlü ve Ünsüz Uyumuna Göre Kelime Sayıları

\begin{tabular}{llllllll} 
& & & Y1 & Y2 & Y3 & Y4 & Y5 \\
\hline \multirow{2}{*}{ Büyük ünlü } & Uyan & 129460 & 155027 & 62710 & 90495 & 91722 \\
& \multirow{2}{*}{ Ünlü Uyumu } & Uymayan & 12398 & 17221 & 6000 & 8317 & 9772 \\
\cline { 2 - 7 } & \multirow{2}{*}{ Küçük ünlü } & Uyan & 135649 & 164719 & 65496 & 94617 & 97317 \\
& & Uymayan & 6209 & 7529 & 3214 & 4195 & 4177 \\
\cline { 2 - 7 } & Her ikisine uyan & 126288 & 151032 & 60995 & 88374 & 89532 \\
& Hiçbirine uymayan & 3037 & 3534 & 1499 & 2074 & 1987 \\
& Sadece birine uyan & 12533 & 17682 & 6216 & 8364 & 9975 \\
\hline \multirow{2}{*}{ Ünsüz Uyumu } & Uyan & 141123 & 171398 & 68390 & 98339 & 101050 \\
& Uymayan & 735 & 850 & 320 & 473 & 444 \\
\hline
\end{tabular}

Ses uyum kurallarına uyma/uymama durumlarına göre kelime sayıları Tablo 21'de verilmiştir;

Kelimelerin \%90.79'unun büyük, \%95.66'sının küçük, \%88.53'ünün hem büyük hem küçük ünlü uyumuna uydukları tespit edilmiştir.

$\checkmark$ Kelimelerin \%99.52'sinin ünsüz uyumuna uyduğu görülmüştür.

Tablo 22. Noktalama İşaretlerinin Kullanım Sayıları

\begin{tabular}{|c|c|c|c|c|c|c|}
\hline & & \\
\hline & & Y1 & Y2 & Y3 & Y4 & Y5 \\
\hline Nokta & . & 15147 & 17878 & 8357 & 13885 & 10378 \\
\hline Üç Nokta & $\ldots$ & 987 & 1609 & 384 & 719 & 653 \\
\hline Virgül & , & 11977 & 13199 & 4939 & 4762 & 9285 \\
\hline Noktalı Virgül & ; & 383 & 502 & 150 & 65 & 599 \\
\hline İki Nokta Üst Üste & $:$ & 2115 & 2476 & 837 & 1688 & 1120 \\
\hline Soru İşareti & $?$ & 1714 & 1579 & 713 & 985 & 874 \\
\hline Ünlem & $!$ & 1943 & 1660 & 575 & 898 & 1253 \\
\hline Tırnak İşareti & “" & 3516 & 2328 & 2924 & 3068 & 2579 \\
\hline Tek Tirnak & 1, & 16 & 40 & 30 & 12 & 210 \\
\hline Kesme İşareti & ' & 1263 & 1563 & 656 & 917 & 987 \\
\hline Yay Ayraç & () & 68 & 86 & 6 & - & 70 \\
\hline Uzun Çizgi (Konuşma Çizgisi) & - & 2287 & 3155 & 535 & 1086 & 1433 \\
\hline
\end{tabular}

Türk Dil Kurumu'nda (2019) yer alan 17 noktalama işaretinin eserlerde bulunma durumları incelenmiş ve kullanım sayıları Tablo 22'de verilmiştir;

$\checkmark 12$ noktalama işareti eserlerde kullanılmıştır.

$\checkmark$ Nokta, en çok; yay ayraç ise en az kullanılan noktalama işaretleridir.

$\checkmark$ Nokta ve virgülün diğer noktalama işaretlerinin kullanım sayılarına oranında yayınevleri arasında \%10'dan fazla farklılık görülmüştür.

Nokta ve virgül dışındaki noktalama işaretlerinin kullanım oranları yayınevlerinde yakın değerdedir. 


\section{SONUÇ}

Bu çalışmada, 5 yayınevinden eserlerin Türkçe DDİ teknikleriyle analizi gerçekleştirilmiştir. Her bir yayınevinden 5 Türk ve 5 dünya edebiyatından aynı isimli eserler çalışmaya dâhil edilmiştir. Özelde eserlere genelde ise Türkçe dil bilgisi kurallarına ve Türkçenin kullanımına ilişkin durumlar ortaya konulmuştur. Sonuçlar tablolarda ayrı sütunlarda sunularak yayınevleri arasındaki olası farklılık ve benzerliklerin daha rahat, kolay ve anlaşılabilir şekilde ortaya konulması amaçlanmıştır.

Eserleri meydana getiren kelimeler, Zemberek tarafından yüksek oranda çözümlenmiştir. Tek harfli, seslenme ifadesi, özel isim, yabancı kelime, söyleyiş farklığı veya yazım yanlışı, çözümlenemeyen kelimelerin ortak özellikleridir. Eserlerdeki ortalama cümle sayısı, bir eserdeki ortalama kelime sayısı ve bir cümledeki ortalama kelime sayısı bakımından yayınevleri arasında ayrışma vardır. En çok kullanılan 7 harf ile en az kullanılan 3 harf tüm yayınevlerinde aynıdır. Düz-yuvarlak, geniş-dar ve kalın-ince sesli harfler ile sert-yumuşak ve süreksiz-sürekli sessiz harflerin kullanımları yayınevleri arasında oransal olarak benzerdir. Yayınevlerinde harflerine göre kelime sayıları birbirlerine yakın değerdedir ve 5 harfli olan kelimelerin oranı fazladır. Tüm yayınevlerinde kelimelerin yaklaşık $1 / 3$ 'ü 3 hecelidir. Hecelerin yarısından fazlası 2 harfli ve sessiz-sesli harf birleşimlidir. Kelimelerin yaklaşık yarısı 5 yayınevinde de 1 çözümlemelidir. 1 çözümlemeli kelime sayısının fazla olması Türkçenin zengin bir dil olduğunun ve her farklı durum için farklı bir kelime kullanıldığının göstergesidir. Kelimelerin ağırlıklı olarak eksiz kullanılması, cümlelerin kısa olmasından ve kelimelerin cümle içinde bağlanması gerekliliğinin olmamasından kaynaklanmaktadır. Yayınevlerinde yapım ekleri genellikle fiil türünden türetimlerde ve fiil türetmek için kullanılmaktadır. Tüm yayınevlerinde kullanılan çekim eki sayısı yapım eki sayısının yaklaşık 4 katıdır ve çekim eklerinin kullanım oranları birbirine yakın değerdedir. Kelimelerin yaklaşık $1 / 2$ si isim, 1/4'ü ise fiil türündedir. Yayınevlerinde kelimelerin büyük bir kısmı ses uyum kurallarına uymaktadır. Ses uyum kurallarına uyan kelimelerin fazla olması Türkçenin kolay konuşulabilir bir dil olduğunun göstergesidir. Eserlerde 17 noktalama işaretinden yalnızca 12 tanesi kullanılmıştır. Tüm yayınevlerinde nokta, en çok kullanılan noktalama işaretidir. Eserlerin metinsel uzunlukları farklı olduğundan yayınevlerindeki noktalama işaretlerinin kullanım sayısı birbirinden faklıdır. Özetle; yayınevleri arasında Türkçe kullanımına ilişkin sonuçlar genel itibariyle benzerlik göstermiştir.

DDİ teknikleri kullanılarak gerçekleştirilen analizler neticesinde bütün yayınevleri ve eserler birlikte değerlendirildiğinde elde edilenler şöyle özetlenebilir;

$\checkmark$ Kelimelerin \%97.93'ü Zemberek tarafından çözümlenebilmiştir.

$\checkmark 7759$ kök/gövde tespit edilmiştir.

$\checkmark \quad$ Alfabede olmayan $Q, X$ ve $W$ harfleri isim ve yer adlarında bulunmaktadır.

$\checkmark$ En çok kullanılan harfler $A, E$ ve $\dot{I}$; en az kullanılan harfler $J, F$ ve $P^{\prime}$ dir.

$\checkmark$ Kelimeler en çok $B, K$ ve $D$; en az $J$, $I$ ve $L$ harfleriyle başlamaktadır.

$\checkmark$ Kelimeler en çok $N, E$ ve $A$; en az $C, B$ ve $J$ harfleriyle bitmektedir.

$\checkmark$ Bigramlar en çok $A, E$ ve $\dot{I}$; en az $J, G$ ve $F$ harfleriyle bitmektedir.

$\checkmark \quad \breve{G}$ harfi dışındaki bütün harflerle başlayan ve $G$ harfi dışındaki bütün harflerle biten en az 1 kelime vardır.

$\checkmark$ Cümleler, ortalama 6.45 kelimedir.

$\checkmark$ Kelimeler, ortalama 5.97 harflidir. 
$\checkmark \quad$ Kelimeler, ortalama 2.55 hecelidir.

$\checkmark$ Heceler, ortalama 2.34 harflidir.

$\checkmark$ Hecelerin \%56.48'i 2 harflidir.

$\checkmark$ Hecelerin \%52.32'si sessiz-sesli harf birleşimli tipindedir.

$\checkmark \quad$ Kelimelerin \%50.68'i kök durumundadır.

$\checkmark \quad$ Kelimelerin \%44.04'ü herhangi bir ek almamıştır.

$\checkmark$ Yapım eklerinin \%66.61'i fiil, \%33.39'u isim türetmektedir.

$\checkmark$ İsim çekim eklerinin kullanım sayısı fiil çekim eklerinin kullanım sayısının yaklaşık 2 katıdır.

$\checkmark$ İyelik eki, en fazla kullanılan çekim ekidir.

$\checkmark$ Çekim eki kullanım sayısı, yapım eki kullanım sayısının yaklaşık 4 katıdır.

$\checkmark \quad$ Kelimelerin yaklaşık yarısı isim türündedir.

$\checkmark \quad$ Ünsüz uyumuna uyan kelimelerin oranı küçük ünlü uyumuna uyanlardan, küçük ünlü uyumuna uyan kelimelerin oranı büyük ünlü uyumuna uyanlardan fazladır.

$\checkmark 17$ noktalama işaretinden 12 tanesi eserlerde yer almaktadır.

$\checkmark$ Yalnızca çözümlenemeyen kelime sayısı, ortalama cümle sayısı, ortalama kelime sayısı, bir cümledeki ortalama kelime sayısı ve noktalama işareti (nokta ve virgül) kullanımında yayınevleri arasında farklılıklar vardır.

$\checkmark$ Şu konularda ise yayınevleri arasında düşük düzeyde farklılıklar vardır;

○ Harflerine göre kelime sayıları oranları,

- Hecelerine göre kelime sayıları oranları,

- Harflerine göre hece sayıları oranları,

- Hece tiplerinin kullanım sayıları,

- Çözümleme sonuçlarına göre kelime sayıları oranları,

- Eklerine göre kelime sayıları oranları,

- Yapım ekleri türlerinin kullanım oranları,

- Çekim ekleri türlerinin kullanım oranları,

- Türlerine göre kelime sayıları oranları,

○ Ünlü ve ünsüz uyumuna uyan/uymayan kelimelerin oranları.

Bu çalışma sonucu elde edilen veriler çeşitli alanlarda kullanılabilir. Örneğin;

$\checkmark$ Sosyal bilimler alanında tematik analizlerde,

$\checkmark$ Eğitim bilimleri kapsamında öğretim teknolojileri ve materyal geliştirmede,

$\checkmark$ Söz dizimi (sentaks), anlambilim (semantik), yapı bilimi (morfoloji) ve söylem (discourse) bağlamında dilbilim araştırmalarında,

$\checkmark$ Ses tanıma, metni sese dönüştürme, metin/veri madenciliği, metin analizi, içerik analizi, söylem analizi kapsamında bilgisayar bilimleri araştırmalarında ve makine çevirisi, özetleme, soru cevaplama, makine-insan etkileşimi kapsamında yapay zekâ araştırmalarında,

$\checkmark$ Disiplinler arası çalışmalarda.

Her ne kadar bu çalışma ile Türkçenin genel karakteri ve Türkçe kullanımının ortaya konulması amaçlansa da elde edilen sonuçlar çalışmanın yapıldı̆̆ı metne göre değişiklik gösterebilir. Örneğin; cümle uzunluğu, bağlaç, noktalama işaretleri veya Türkçeye ait diğer unsurların kullanımı edebi eserlerde, bilimsel makalelerde veya köşe yazılarında farklılaşabilmektedir. Bu sebeple; farklı türde içerikler barındıran metinsel verilerle de çalışma yürütülerek Türkçenin karakteri ve kullanım yapısı, geneli yansıtacak şekilde karşılaştırmalı olarak ortaya konulabilir. 


\section{SUMMARY}

Publishers prepare and publish literary works from Turkish and world literature for the stages of primary, secondary and high schools. 5 literary works from Turkish and 5 from world literature having the same title prepared for the secondary school students out of 5 publishers were used in this study. Contents of these works works written in natural languages were analyzed with Turkish NLP techniques. It is aimed to reveal Turkish grammar rules and Turkish use in general and examine literary works specifically. Zemberek, NLP Library not only for Turkish but also for Turkic languages, were used in the examination of the words, determination of root/stem, spelling, affixation and identification of the types of the words. Other procedures except these were realized with the software specifically developed in C\# language in Visual Studio environment for this study. Zemberek can analyze many of the words. In spite of the results which were obtained via analyses of literary works were found out as similar in terms of proportion, differences were found out in terms of unanalysable word number, average sentence number of literary works, average word number in literary works, average word number in a sentence and and the ratio of the use of dot and comma among publishers. When all the literary works are taken into consideration together, the following results were obtained: the average number of words in a sentence is 6.45 , the average number of letters of words is 5.97 , the average number of syllables of words is 2.55 and the average number of letters in syllables is 2.34 . While the letters of $A, E$ and $I$ were the most used letters in literary works, $J, F, P$ were the least used ones. Words mostly begin with the letters of $B, K$ and $D$, rarely begin with the letters of $J, I$ and $L$, and words mostly end with the letters of $N, E$ and $A$, rarely end with the letters of $C$, $B$ and $J$. Bigrams mostly end with the letters of $A, E$ and $\dot{I}$, rarely end with the letters of $J, G$ and $F$. The most used syllable type is consonant-vowel (CV) and the least used syllable type is vowel-consonant-consonant (VCC) in the literary works. Most of the words were in accordance with the vowel and consonant harmonies. Moreover, approximately half of the words were in root form, in noun class and they were used without any affixation. The total number of use of inflectional suffixes was much more than derivational suffixes. The number of verb inflection suffix use is approximately half of the noun inflection suffix use. The number of verb derivational suffix is more than the noun derivational suffix. 12 punctuation marks out of 17 were included within the literary works. However, it was seen that the contents of literary works with the same name, which are prepared and published by different publishing houses, may differ partly or completely from each other.

\section{Makale Bilgileri}

\begin{tabular}{ll} 
Etik Kurul Kararı: & Etik Kurul Kararından muaftır. \\
Katılımcı Rızası: & Araştırma Makalesi/Katılımcı yoktur \\
Mali Destek: & Çalışma için herhangi bir kurum ve projeden mali destek alınmamıştır. \\
Çıkar Çatışması: & Çalışmada kişiler ve kurumlar arası çıkar çatışması bulunmamaktadır. \\
Telif Hakları: & Telif hakkına sebep olacak bir materyal kullanılmamıştır. \\
Article Information & \\
\hline $\begin{array}{l}\text { Ethics Committee Approval: } \\
\text { Informed Consent: }\end{array}$ & Exempt from the Ethics Committee Decision. \\
Financial Support: & Research Article/No participant \\
Conflict of Interest: & No financial support from any institution or project. \\
Copyrights: & No conflict of interest.
\end{tabular}




\section{KAYNAKÇA}

Akarsu, C. \& Diri B. (2016). Twitter ile Türk televizyonları rating tahmini. IEEE 24. Sinyal İsleme ve Uygulama Kurultayı, Zonguldak.

Akçay, E. (2009). 100 Temel Eser'in kelime kazanımı açısından değerlendirilmesi (MEB tarafından ilköğretim II. kademe için önerilen 100 Temel Eser'den seçilen beş eser örneğinde) (Yüksek lisans tezi). Abant İzzet Baysal Üniversitesi, Bolu.

Akın, M. D. \& Akın A. A. (2007). Türk dilleri için açık kaynaklı doğal dil işleme kütüphanesi: Zemberek. Elektrik Mühendisliği, 431, 38-44. Erişim adresi: http://www.emo.org.tr/ekler/c7a625d5077d3ba_ek.pdf?dergi=483.

Aktan, O. (2012). 100 Temel Eserlerde yer alan değerlerle sosyal bilgiler öğretim programındaki değerlerin uyumu (Yüksek lisans tezi). Düzce Üniversitesi, Düzce.

Alemdar Özer, B. (2012). Ortä̈̆gretim için belirlenen 100 Temel Eser serisinin Türk dili ve edebiyatı eğitiminin genel amaçları çerçevesinde incelenmesi (Yüksek lisans tezi). Dokuz Eylül Üniversitesi, İzmir.

Amasyalı, M. F. \& Diri B. (2005). Bir soru cevaplama sistemi: BayBilmiş. Türkiye Bilişim Vakfı Bilgisayar Bilimleri ve Mühendisliği Dergisi, 1(1), 37-51. Erişim adresi: https://dergipark.org.tr/tr/pub/tbbmd/issue/22240/238746.

Arı, G. \& Okur A. (2014). Öğrencilerin ilköğretim 100 Temel Eseri okuma durumu. Türkiye Sosyal Araştırmalar Dergisi, 173, 307-328. Doi: 10.20296/tsad.40333.

Arıcan, S. \& Yılmaz B. (2010). 100 Temel Eser uygulamasının öğrencilerin okuma alışkanlıklarına etkisi ve bu uygulamada kütüphanelerin rolü konusunda öğretmen görüşleri. Türk Kütüphaneciliği, 24(3), 495-518. Erişim adresi: https://dergipark.org.tr/tr/pub/tk/issue/48861/622505.

Arıcan, S. (2010). 100 Temel Eser uygulamasının öğrencilerin okuma alı̧skanlıklarına etkileri konusunda öğretmen görüşleri (Yüksek lisans tezi). Hacettepe Üniversitesi, Ankara.

Arslan, A. (2016). DeASCIIfication approach to handle diacritics in Turkish information retrieval. Information Processing $\mathcal{E}$ Management, 52(2), 326-339. Doi: 10.1016/j.ipm.2015.08.004.

Aydin, G. \& Hallac İ. R. (2015). Document classification using distributed machine learning. 2nd International Conference on Advances in Information Processing and Communication Technology, Roma.

Bayraktar Erten, N. (2016). Küçük Prens romanının Türkçe ve Azerbaycanca çevirilerinde deyimler ve atasözlerinin kullanımı. Sanal Türkoloji Araştırmaları Dergisi, 1(2), 1-8. Erişim adresi: https://dergipark.org.tr/tr/pub/stad/issue/34131/377531.

Birkan Baydan, E. (2008). Visibility of translation through conflicting ideologies: The 'Islamic' retranslations of '100 Essential Readings' (Yüksek lisans tezi). Boğaziçi Üniversitesi, İstanbul.

Ceran, D. (2015). Yüz Temel Eser listesi Türk edebiyatı kategorisinde yer alan kitapların okunabilirlik düzeyleri ile yedinci sınıf öğrencilerinin kitaplar hakkındaki görüşlerinin değerlendirilmesi. Uluslararası Dil ve Edebiyat Eğitimi Dergisi, 4(14), 23-51. Erişim adresi: http://www.idealonline.com.tr/IdealOnline/lookAtPublications/paperDetail.xhtml?uId= 18526. 
Çakiroğlu, Ü. \& Özyurt Ö. (2006). Türkçe metinlerdeki yazım yanlışlarına yönelik otomatik düzeltme modeli. Elektrik-Elektronik-Bilgisayar Mühendisliği Sempozyumu ve Fuarı, Bursa.

Çalışkan, A. (2016). İlköğretim 100 Temel Eser içerisinde yer alan dünya edebiyatına ait eserlerin değerler eğitimi açısından incelenmesi (Yüksek lisans tezi). Necmettin Erbakan Üniversitesi Eğitim Bilimleri Enstitüsü, Konya.

Çer, E. (2016). Türkçe öğretiminde çocuğa görelik ilkesine uygun edebiyat yapıtlarının önemi. İlköğretim Online, 15(4), 1399-1410. Doi: 10.17051/io.2016.22814.

Çer, E. (2017). Türkçe öğretmenlerinin "Türkçe öğretimine" yönelik yeterlilikleri. Pamukkale Sosyal Bilimler Enstitüsü Dergisi, 26, 68-89. Doi: 10.5505/pausbed.2017.85579.

Çifçi, M. \& Ulutaş M. (2017). İlköğretim 100 Temel Eser listesindeki kitapların hedef kitlenin düzeyine uygunluğu. Turkish Studies, 12(18), 235-270. Doi: 10.7827/TurkishStudies.12149.

Çocuk Vakfı (2009). 100 Temel Eser raporu. İstanbul: Çocuk Vakfı Yayını.

Doğan, B. (2011). 100 Temel Eserde 6, 7 ve 8. siniflar için önerilen ortak kitaplar üzerine bir araştırma (Yüksek lisans tezi). İnönü Üniversitesi, Malatya.

Eker, C. \& Yıldırım K. (2017). Değerler eğitimi açısından Ziya Gökalp' e ait Altın Işık adlı eserin incelenmesi. Karaelmas Eğitim Bilimleri Dergisi, 5(1), 30-38. Erişim adresi: http://ebd.beun.edu.tr/index.php/KEBD/article/view/105.

Erdemir, Z. E. (2016). 100 Temel Eser listesinde yer alan masallardaki bibliyoterapik unsurlar (Yüksek lisans tezi). Muğla Sıtkı Koçman Üniversitesi, Muğla.

Gedik, F. (2012). Sosyal bilgiler programında yer alan değerlerin kazandırlmasında 100 Temel Eser içerisinde yer alan hikâye kitaplarının rolü (Yüksek lisans tezi). Atatürk Üniversitesi, Erzurum.

Gunduz, H. \& Cataltepe Z. (2015). Borsa Istanbul (BIST) daily prediction using financial news and balanced feature selection. Expert Systems with Applications, 42(22), 9001-9011. Doi: 10.1016/j.eswa.2015.07.058.

Güzelküçük, Ş. (2019). 100 Temel Eser listesinde yer alan masal kitaplarinda korku ve şiddet ögeleri (Yüksek lisans tezi). Kırşehir Ahi Evran Üniversitesi, Kırşehir.

Hengirmen, M. (2007). Türkçe dilbilgisi. Ankara: Engin Yayınları.

İspir, S. (2013). İlköğretim öğrencilerine tavsiye edilen 100 Temel Eser listesinde yer alan Türk yazarlara ait eserlerde kullanılan deyimler ve atasözlerinin kullanım sıklı̆̆ üzerine bir inceleme (Yüksek lisans tezi). Abant İzzet Baysal Üniversitesi, Bolu.

Kantar, Ş. (2014). Ilköğretim 4. ve 5. sinıf sosyal bilgiler dersinde 100 Temel Eser yoluyla değerler eğitimi (Yüksek lisans tezi). Necmettin Erbakan Üniversitesi, Konya.

Kara, M. \& Ulutaş M. (2018). Gazi Üniversitesi Vakfı Özel Anadolu Lisesi öğrencilerinin kelime hazinesinin derlem tabanlı incelenmesi. Uluslararası Türkçe Edebiyat Kültür Eğitim Dergisi, 7(3), 1902-1916. Doi: 10.7884/teke.4300.

Karaağaç, G. \& Yavuzer H. (2011). Türk dili ve kompozisyon. Ankara: Okutman Yayıncllık.

Karakaş, Ö. (2013). 8. simı öğrencilerinin okuma tutumları üzerine bir araştırma: MEB tarafından ortaokul öğrencilerine önerilen 100 Temel Eser örneğinde (Yüksek lisans tezi). Afyon Kocatepe Üniversitesi, Afyon. 
Karaman Kepenekci, Y. \& Aslan C. (2013). Ortaöğretim okullarına önerilen 100 Temel Eser'deki romanlarda insan hakları üzerine bir çözümleme. Ĕ̆itim ve Bilim, 38(168), 183197. Erişim adresi: http://egitimvebilim.ted.org.tr/index.php/EB/article/view/1346.

Kılıç, A. \& Aktan O. (2015). İlköğretim okulları için tavsiye edilen 100 Temel Eserde vurgulanan değerler. Illköğretim Online, 14(1), 243-275. Doi: 10.17051/io.2015.45177.

Kılıç, U. (2010). Çeviri çocuk klasiklerinde eğitici iletiler (MEB'in 2005 yılında ilköğretim öğrencilerine önerdiği 100 Temel Eser örneğinde) (Yüksek lisans tezi). Afyon Kocatepe Üniversitesi, Afyon.

Kızılkaya, A. (2012). 100 Temel Eser içerisindeki hikâye ve romanlarda işlenen ahlâkî konuların eğitsel yönden değerlendirilmesi (Yüksek lisans tezi). Necmettin Erbakan Üniversitesi, Konya.

Kurttekin, F. (2013). MEB tarafindan tavsiye edilen 100 Temel Eserden popüler olan on kitap örneğinde dinî ve ahlâkî değerler (Yüksek lisans tezi). Uludağ Üniversitesi, Bursa.

Kuşçu, E. (2015). Çeviride yapay zekâ uygulamaları. Atatürk Üniversitesi Kazım Karabekir Eğitim Fakültesi Dergisi, 30, 45-58. Erişim adresi: https://dergipark.org.tr/tr/pub/ataunikkefd/issue/2789/37502.

Millî Eğitim Bakanlığı. (2005, 4 Ağustos). 100 Temel Eser genelgesi. Erişim adresi: http://mevzuat.meb.gov.tr/dosyalar/1405.pdf.

Millî Eğitim Bakanlığı. (2018, 17 Aralık). 100 Temel Eser listesi genelgelerinin yürürlükten kaldırılması genelgesi. Erişim adresi: http://mevzuat.meb.gov.tr/dosyalar/1993.pdf.

Okur, A. (2007). Serbest okuma etkinliğinin sözcük hazinesi ve kavram gelişimine etkisi (MEB tarafindan ilköğretim II. kademe öğrencilerine önerilen 100 Temel Eser örneğinde) (Doktora tezi). Marmara Üniversitesi, İstanbul.

Özdoğan Şahin, N. (2018). Temel eğitim okulları için tavsiye edilen 100 Temel Eserde engellilik (Yüksek lisans tezi). Trakya Üniversitesi, Edirne.

Özdoğan, A. G. \& Turan M. (2019). Metin madenciliği kullanarak İngilizce doküman sinuflama. İstanbul Ticaret Üniversitesi Teknoloji ve Uygulamah Bilimler Dergisi, 2(1), 37-46. Erişim adresi: http://tub.ticaret.edu.tr/jtas/article/view/71/26.

Öztürk, H. (2013). İlköğretim 100 Temel Eser'deki manzum metinlerde değerler (Yüksek lisans tezi). Necmettin Erbakan Üniversitesi, Konya.

Paksu, Z. (2010). M.E.B'in 2005 yılında tavsiye ettiğgi 100 Temel Eserde söz varlığı üzerine bir araştırma (Yüksek lisans tezi). Marmara Üniversitesi, İstanbul.

Parlak, M. (2014). MEB tarafindan tavsiye edilen 100 Temel Eserin okunma oranlar ve okunma sebepleri üzerine bir araştırma (Erzurum ili örneği) (Yüksek lisans tezi). Atatürk Üniversitesi, Erzurum.

Sivrikaya, Ü. (2010). Illköğretimde küresel değerler 100 Temel Eser üzerine bir inceleme (Yüksek lisans tezi). Niğde Üniversitesi, Niğde.

Süngü, E. (2011). Milli Eğitim Bakanlığının tavsiye ettiğgi 100 Temel Eser'deki hikâye kitaplarmın ilköğretim ikinci kademe öğrencilerinin zihinsel becerilerini geliştirmedeki işlevleri (Yüksek lisans tezi). Başkent Üniversitesi, Ankara.

Şen, Ü. (2007). Millî Eğitim Bakanlı̆̆ı'nın 2005 yılında tavsiye ettiği 100 Temel Eser yoluyla Türkçe eğitiminde değerler öğretimi üzerine bir araştırma (Yüksek lisans tezi). Gazi Üniversitesi, Ankara. 
Tenekeci, M. (2011). Illköğretim 6. sını öğrencilerinin yazılarındaki söz dizimi ile Milli Eğitim Bakanliğı tarafindan belirlenen 100 Temel Eser listesinde yer alan kitaplardaki söz dizimlerinin karşılaştırılması: Kilis örneği (Yüksek lisans tezi). Kilis 7 Aralık Üniversitesi, Kilis.

Tozoğlu, S. (2009). T.C. Milli Eğitim Bakanlı̆̆g'nca ilköğretim için tavsiye edilen 100 Temel Eser içerisindeki Türk edebiyatına ait romanların atasözleri ve deyimler bakımından incelenmesi (Yüksek lisans tezi). Selçuk Üniversitesi, Konya.

Türk Dil Kurumu. (2019, 10 Mart). Noktalama işaretleri. Erişim adresi: http://tdk.gov.tr/icerik/yazim-kurallari/noktalama-isaretleri-aciklamalar/.

Türkyılmaz, M. \& Kuş Z. (2014). İlköğretim 100 Temel Eserde çocuk hakları. Uluslararası Avrasya Sosyal Bilimler Dergisi, 5(15), 39-63. Erişim adresi: http://www.ijoess.com/Makaleler/852860406_4-zafer\%20ku\%c5\%9f.pdf.

Ulutaş, M. (2011). Ilköğretim 100 Temel Eser listesindeki kitapların hedef kitlenin düzeyine uygunluğu (Yüksek lisans tezi). Uşak Üniversitesi, Uşak.

Uzundere, E., Dedja, E., Diri, B. \& Amasyalı M. F. (2008). Türkçe haber metinleri için otomatik özetleme. Akıllı Sistemlerde Yenilikler ve Uygulamaları Sempozyumu, Adana.

Yılmaz, İ. (2018). A corpus investigation on the journal of social sciences of the Turkic world. Universal Journal of Educational Research, 6(6), 1199-1206. Doi: 10.13189/ujer.2018.060610.

Yurtseven, H. (2011). MEB onaylı 100 Temel Eserde yer alan çeviri kitaplardaki iletilerin ilköğretim ikinci kademe öğrencilerine uygunluğunun Türkçe öğretmenlerinin görüşleri doğrultusunda incelenmesi (Yüksek lisans tezi). Uludağ Üniversitesi, Bursa.

Yükseköğretim Kurulu Başkanlığı. (2019, 24 Temmuz). Ulusal tez merkezi. Erişim adresi: https://tez.yok.gov.tr/UlusalTezMerkezi/.

Yüksel, A. S. \& Tan F. G. (2018). Metin madenciliği teknikleri ile sosyal ağlarda bilgi keşfi. Mühendislik Bilimleri ve Tasarm Dergisi, 6(2), 324-333. Doi: 10.21923/jesd.384791.

Zemberek. (2015, 12 Temmuz). Açık kaynak kodlu türkçe doğal dil işleme kütüphanesi. Erişim adresi: http://code.google.com/p/nzemberek. 